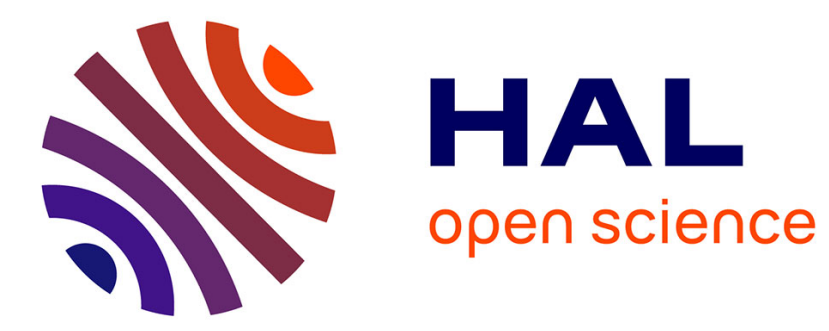

\title{
Labor Market and Access to Justice
}

Romain Espinosa, Claudine Desrieux, Marc Ferracci

\section{To cite this version:}

Romain Espinosa, Claudine Desrieux, Marc Ferracci. Labor Market and Access to Justice. International Review of Law and Economics, 2018, 54, pp.1-16. 10.1016/j.irle.2017.09.008 . halshs-01634209

\section{HAL Id: halshs-01634209 \\ https://shs.hal.science/halshs-01634209}

Submitted on 14 Nov 2017

HAL is a multi-disciplinary open access archive for the deposit and dissemination of scientific research documents, whether they are published or not. The documents may come from teaching and research institutions in France or abroad, or from public or private research centers.
L'archive ouverte pluridisciplinaire HAL, est destinée au dépôt et à la diffusion de documents scientifiques de niveau recherche, publiés ou non, émanant des établissements d'enseignement et de recherche français ou étrangers, des laboratoires publics ou privés. 


\title{
Labor Market \& Access to Justice
}

\author{
Romain Espinosa*, Claudine Desrieux ${ }^{\dagger}$ And MarC Ferracci ${ }^{\ddagger}$
}

September 2017

\begin{abstract}
In 2008, the French government enacted a reform that reduced the number of labor courts by one quarter. This led to significant changes in access to labor courts for many workers and employers who had to travel further to proceed with conflict litigation. We use this reform to evaluate how access to labor courts affects the labor market. Our empirical approach mainly relies on regression-adjusted conditional differences-in-differences estimations. We find that cities that experienced an increase in the distance to their associated labor court suffered from a lower growth rate of job creation (-4 percentage points), job destruction (-4.6 pp) and firm creation (-6.3 pp) between 2007 and 2012 compared to unaffected cities. We find opposite but insignificant effects for cities that experienced a fall in the distance to the labor court. These results emphasize the central role of labor courts for the good functioning of the labor market.
\end{abstract}

JEL codes: K31, K41.

Keywords: Job creation; job destruction; firm creation; labor courts; judicial reform.

\section{Introduction}

The rationalization of the court system has become a popular proposal in order to cut public expenditure in European countries. The 2011 Vilnius declaration, issued by the European Network of Councils for the Judiciary, urged European countries to reform their judicial framework and, more specifically, to rationalize and reorganize their court system. As a consequence, many European countries reduced the number of their courts, such as France and Portugal in 2008, Croatia in 2010,

\footnotetext{
${ }^{*}$ CRED (TEPP), University Paris II, 12 Place du Panthéon, 75005 Paris, France. E-mail: romain.espinosa@uparis2.fr

${ }^{\dagger}$ Corresponding Author. CRED (TEPP), University Paris II, 12 Place du Panthéon, 75005 Paris, France. Tel.: $+33(0) 44418991$. E-mail: claudine.desrieux@u-paris2.fr

${ }^{\ddagger}$ CRED (TEPP), University Paris II, 12 Place du Panthéon, 75005 Paris, France., \& LIEPP Sciences Po, 27 rue saint-guillaumme, 75007 PARIS, France, \& CREST. E-mail: marc.ferracci@ensae.fr
} 
Italy in 2011, and Belgium and the Netherlands in 2013. Similar reforms have been implemented or debated in Norway, Sweden and Germany.

The costs and benefits associated with these reforms are usually difficult to establish. On the one side, public decision-makers hope to cut public expenditure by reducing the number of public facilities and public employees. On the other hand, these reforms entail reorganizational costs, and are likely to hinder access to justice as the geographical distance between courts and litigants increases. Institutions, and especially judicial institutions, are known to be key determinants of economic and financial outcomes (Acemoglu and Johnson (2005)). Reducing the effective access to justice services can therefore potentially inflict great damage on economic activity, therefore making the reforms less attractive.

In this paper, we consider the 2008 French reform that closed almost one quarter of labor courts. The purpose of this reduction was to cut public expenditure. The number of labor courts dropped from 271 to 210, although the number of judges remained constant. Some courts increased their levels of activity with a wider geographical jurisdiction. However, the reform sparked off great debate, both before and after its implementation. Opponents feared that some litigants would be prevented from going to court, were the distance to their new local court to rise (Sénat (2012)). ${ }^{1}$ The evaluations of the global costs and benefits of the reform are still being discussed (Ministère de la Justice (2011); Sénat (2012); Cour des comptes (2015)). Given the challenge many European countries currently face with respect to employment, we here propose to evaluate the impact of this reform on the labor market.

We use panel data on labor-market conditions at the city level to estimate the effects of the removal of labor courts. After the reform, areas that were previously under the jurisdiction of the removed courts were reallocated to unaffected courts. The reform thus changed the distance between some cities and their associated labor courts. The distance rose for many cities, and fell in some others. This situation allows us to establish how geographical access to courts affects job creation, job destruction, unemployment and firm creation.

Our main empirical challenge is to separate the causal impact of the reform from a possible selection effect reflecting the government's choice of which courts to remove (Espinosa, Desrieux and Wan, 2017). We address this in two ways. First, we run panel regressions using a differencesin-differences approach and assess the validity of the Common Trend Assumption. Second, we rely on matching methods to increase the comparability of the cities that were affected and unaffected by the reform, and run conditional differences-in-differences estimations.

We find strong evidence for a negative effect of labor-court removal on the labor market when the reform increased the distance to the labor court. The growth rate between 2007 and 2012 in job creation was 4 percentage points lower for cities with a rise in distance compared to unaffected cities; the analogous figures for job destruction and firm creation are 4.6 and 6.3 percentage points respectively. The labor market has thus become less fluid and less dynamic. We find the opposite results for cities which experienced a fall in the distance to their labor court following the reform, although the effects are not statistically significant.

This is the first piece of academic research to document the effect of the rationalization of the judiciary on economic activity. It provides public decision-makers with empirical information

\footnotetext{
${ }^{1}$ See also the debates reported in newspapers, such as that in Le Monde dated 13/7/2012: http: //www.lemonde.fr/societe/article/2012/07/13/la-reforme-de-la-carte-judiciaire-une-occasionmanquee-selon-la-commission-des-lois-du-senat_1733397_3224.html.
} 
to better anticipate the impact of similar reforms in other countries. Our results call for careful reflection regarding these reforms, as justice accessibility is shown to affect economic outcomes. In the light of the French experience, the reduction in the number of labor courts has made the labor market less flexible.

The remainder of the paper is structured as follows. Section 2 relates our work to the previous economic literature. Section 3 presents the French reform and its economic and institutional context. Section 4 then describes our data, and the empirical analysis appears in Section 5. Last, Section 6 discusses our results and concludes.

\section{Literature}

The empirical literature on the impact of the judiciary on economic activity has continued to grow over the years. From the seminal contributions of Djankov et al. (2003) and Acemoglu and Johnson (2005), the role and design of judicial institutions have been analyzed to better understand their economic effects and provide practical recommendations for public decision-makers. For instance, Chemin (2009) considers a reform carried out by the Pakistani government in 2002 to provide judges with more training. The results show that judges took care of a quarter more cases and the entry rate of new firms increased by one half due to the reform. Using Indian data, Chemin (2012) shows that reforms in the organization of the judiciary to speed up the resolution of civil suits led to fewer breaches of contract, encouraged investment, and facilitated access to finance. More related to court organization, Visaria (2009) and Von Lilienfeld-Toal et al. (2012) analyze the introduction of debt-recovery tribunals in India to speed up debt-recovery claims. They show that this reform reduced delinquency for the average loan and lowered the interest rates charged on larger loans, holding borrower quality constant. The reform reduced credit access for small borrowers, and expanded it for wealthy borrowers. These papers have mainly exploited spatial variations in reform implementation in order to identify its effects.

Our paper is related to the above work by investigating how changes in the judiciary feed through to economic outcomes. However, we differ in a number of ways. First, we focus on a reduction in the number of courts, while the above work focused on changes in procedural rules or the creation of new courts. Governments and international organizations (World Bank (2011); Sénat (2012); ENCJ (2012)) recommend the rationalization of courts, yet there is little empirical evaluation of the judicial map. Second, we rely on French data, while the previous work has used data from developing countries. Since many developed countries are debating whether to reduce the number of courts, the evaluation of a reform in a developed country seems apposite. Third, we focus on labormarket outcomes, which are currently one of the biggest challenges faced by public decision-makers. Last, our empirical strategy relies on differences-in-differences and matching regressions instead of spatial variation, as the reform was implemented over the whole territory at the same time but did not affect all cities. This is a common phenomenon, so that our methodological techniques can be replicated in further work.

To date, legal scholars (Gomes (2007); Mak (2008); Van Djik and Horatius (2013)) and international institutions have expressed concern about access to courts and their geographical allocation. These topics have however received less attention in the economic literature. Chappe and Obidzinski 
(2014) model how the distance to court affects both the demand for litigation and the probability of accidents via the level of care chosen by individuals. When the probability of accidents depends on the level of care chosen by the parties, increased distance to court may bring about higher levels of care: parties want to avoid accidents that lead to potentially costly litigation. Espinosa et al. (2017) empirically analyze how the 2008 French reform that reduced the number of labor courts by almost a quarter affected the demand for litigation and average case duration in the remaining courts. Case duration rose, and the demand for litigation fell more significantly in areas where courts had to deal with a higher level of new claims coming from the removed courts. We here go one step further to determine whether the reform influenced the labor market. By changing the distance to labor courts, the reform may have changed employers' decisions to hire and fire employees or create new firms.

To a lesser extent, our paper is also related to the literature on firing costs. Changing access to courts can be perceived as a change in litigation costs, and so firing costs, for the parties concerned. Most work suggests that higher firing costs reduce employment. For instance, Kugler and Pica (2008) use Italian panel data to consider the impact of a reform increasing unjust dismissal costs for businesses with fewer than 15 employees, while not changing these costs for larger businesses. The higher dismissal costs reduced job creation and destruction in small relative to large firms, especially in sectors with greater employment volatility. They also find some evidence that the reform reduced firm entry rates and employment adjustments, but had no effect on exit rates. ${ }^{2}$ Similar results have been replicated in different institutional environments (Kugler and Saint-Paul (2004), Hernanz et al. (2005), Behaghel et al. (2008)). ${ }^{3}$ In a different set-up, Gianfreda and Vallanti (2015) investigate the effect of the duration of labor litigation on the composition of employment. They find that longer litigation increases job creation for women and young people in both temporary and permanent jobs, while it produces a switch from permanent to temporary jobs for workers in the middle age range. The closest paper to ours is Fraisse et al. (2014), who analyze the French judicial process and its effect on the labor market. They use lawyer density as a proxy for judicial fees, and find that greater density leads to more litigation. This increased filing rate, and thus increased firing costs, brings about a large fall in employment fluctuations, especially for shrinking or exiting firms. However, it also leads to a small positive effect on net employment growth. We depart from this work by using a different identification strategy to measure the impact of litigation costs on employment decisions, namely the 2008 reform of the judicial map of labor courts.

\section{The institutional context}

\subsection{The French labor market}

According to the French National Statistical Institute (INSEE), 25.5 million people in France were working in 2015. ${ }^{4}$ About three out of four jobs are in the service sector, and almost nine out of

\footnotetext{
${ }^{2}$ Other work has shown that the proportion of firms with under 15 employees was reduced after the reform (Garibaldi et al. (2003); Schivardi and Torrini (2008)).

${ }^{3}$ Two other contributions, Bauer et al. (2007) and von Below and Thoursie (2010), suggest that lower firing costs that may be applied to small firms have no significant impact on job creation and job destruction.

${ }^{4}$ The employment rate of people between 15 and 64 years of age is at the European Union average, i.e. around $64 \%$.
} 
ten workers are salaried. In this respect, proper enforcement of labor contracts is a real concern for French workers. More precisely, in 2015, 85.6\% of these salaried workers held an open-ended contract (permanent/regular/long-term jobs, called contrats à durée indéterminée: CDI), and 13.5\% had a fixed-term contract (temporary/short-term job). The good functioning of the labor market then reflects the appropriate regulation of the contractual employment relationship.

As for many European countries, France suffers from a high level of unemployment (10\% of the labor force according to the ILO definition, i.e. 2.9 million people). Regional disparities are large: some cities have unemployment rates over $33 \%$ while for others this figure is below $8 \%$.

In addition, 554,000 firms were created in France in 2016. Around 40\% of these were "autoentrepreneurs", i.e. firms with a special status (enacted in 2009) for individual activity with limited sales revenue (self-employment). The other creations were public limited-liability companies (34\%) and individual enterprises other than "auto-entrepreneurs" (26\%). ${ }^{5}$ Overall, there are 2.42 million firms in France (excluding the self-employed) and 86\% of these are small, employing fewer than 10 employees. ${ }^{6}$

By enforcing labor contracts, labor courts are key institutions for employment protection. According to the OECD indicators, employment protection legislation (EPL) in France is fairly high: on a scale from zero (fewest restrictions) to six (most restrictions), the overall EPL indicator for France is 2.38, whereas the OECD average is $2.04 .^{7}$ One side effect of this stringent EPL is " $t o$ produce a large amount of legal procedures related to labor disputes" (Le Barbanchon and Malherbet (2013)). Those disputes are brought to the French labor courts, called "Conseils des prud'hommes".

\subsection{French Labor Courts}

Labor courts are first-level tribunals, ${ }^{8}$ dealing with individual disputes affecting labor relationships in the private sector only (e.g. the validity of employment contracts, canceling dismissals, monetary compensation and the level of severance payments). ${ }^{9}$ There are currently 210 courts spread out all over France, each of which has jurisdiction over a certain geographical area determined by the law. The territorial jurisdiction for a claim is determined by the location of the establishment in which the work takes place and, if the work is not carried out in an establishment, by the residence of the employee.

Each court is divided into five sections by activity (agriculture, commerce, industry, executives and diverse activities). The judges in labor courts are not professional but are rather elected representatives (on a parity basis in each section) of employees and employers. ${ }^{10}$

\footnotetext{
${ }^{5}$ Source: https://www.insee.fr/fr/statistiques/2562977 (Last Access: April 2017).

${ }^{6}$ Source: https://www.insee.fr/fr/statistiques/1379753\#consulter (Last Access: April 2017).

${ }^{7}$ These figures relate to the indicator "Strictness of employment protection - individual and collective dismissals (regular contracts)" and come from the OECD website: http://stats.oecd.org/Index.aspx?DataSetCode=EPL_R (Last access: October 2015). Note that the indicator for the strictness of employment protection regarding temporary contracts was 3.63 for France in 2013, and 1.72 on average in OECD countries.

${ }^{8}$ Appeals are brought before the "Cour d'Appel" ("Chambre sociale"), and appeals against the "cour d'appel"s decisions are lodged with the "Cour de cassation" ("Chambre sociale").

${ }^{9}$ These courts only deal with individual disputes, as disputes affecting collective labor relationships (such as strikes) are dealt with by ordinary civil courts ("Tribunal de grande instance"). However, if people individually challenge their dismissal that is part of a collective dismissal, they do so in the labor courts.

${ }^{10}$ The last election was held in 2008. From 2018, the nomination conditions of the lay judges will change, according to the law No.2014 - 1528 of December $18^{\text {th }} 2014$.
} 
Between 2004 and 2013, around 200,000 cases were brought to labor courts each year in France (Guilloneau and Serverin (2015)). Cases suffer from long delays and take about 12 months to be resolved, whereas civil and commercial courts make decisions in half the time (respectively 5.4 and 5.8 months on average).

Labor courts mainly deal with dismissals. In 2013, 8 out of 10 plaintiffs' claims asserted the breach of their employment contract (Guilloneau and Serverin (2015)), with $76 \%$ of claims contesting dismissals for personal reasons. ${ }^{11}$ Since July $13^{\text {th }} 1973$, firms have to provide a real and serious cause of termination ("cause réelle et sérieuse") to dismiss a worker. The French Labor Code does not provide any definition of real and serious causes, nor a list of situations considered as such. The content and scope of this notion has instead been defined by French case law, leading to many difficulties in interpretation that help explain the large number of litigated cases.

\subsection{Overview of the 2008 Reform}

The reform to reduce the number of French courts was discussed and implemented in 2008. This reform aimed to $(i)$ reduce the gap between demographics and the allocation of courts in the country, and (ii) rationalize the court network. ${ }^{12}$ In 2015, the total cost of this reform was evaluated at $413 \mathrm{M} €$, and the savings on administrative expenditures at $9.1 \mathrm{M} €$ per year (Cour des comptes (2015)). ${ }^{13}$ Before the reform, there were 1,206 courts in France, of which 271 were first-level labor courts. Access to courts was very unequal: some Départements ${ }^{14}$ had up to 14 labor courts, while others had only one (Sénat (2012)). The reform was enacted by decree $n^{0} 2008-514$ of May $29^{\text {th }}$ 2008, and removed 62 labor courts, i.e. over $20 \%$ of the 271 initial labor courts. One court was created, so that the total number of labor courts fell to 210 after the reform. The judicial map was redrawn: areas with removed courts were reassigned to the other remaining labor courts. This reform was introduced on December $3^{\text {rd }} 2008 .{ }^{15}$ There were two main criteria for removal. First, public authorities were willing to maintain at least one labor court per "Département". ${ }^{16}$ Second, public decision-makers primarily targeted low-activity courts (fewer than 500 new cases each year). Appendix 1 shows the judicial map of French labor courts before and after the reform.

\footnotetext{
${ }^{11}$ Around $30 \%$ of dismissals are challenged in court (Tresor-Eco (2014)), and one out of four dismissals for personal reasons is brought to court. Pursuant to Article L. 1233-3 of the French Labor Code, a dismissal can only be considered as economically grounded if it is based on a reason unrelated to the employee and caused by economic difficulties or technical changes. On the contrary, dismissals for personal reasons may reflect disciplinary problems (e.g. refusal to follow work instructions) or other case-to-case issues (professional inability or repeated errors, for instance).

${ }^{12}$ The last general reform regarding the number of courts in France dated back to 1958. Another smaller reform targeting only labor courts was implemented in 1992: 11 labor courts were removed.

${ }^{13}$ These figures come from the institution in charge of evaluating the public organizations and public services in France (the Cour des Comptes). They cover the entire reform. Note that this reform concerned not only labor courts but also civil and commercial courts. Overall, 341 courts were removed, of which 62 were labor courts.

${ }^{14}$ Départements are French administrative subdivisions of the territory. Metropolitan France is made up of 95 Départements that are themselves divided up into "cantons" that serve as constituencies for the election of the members of the representative assembly in each department. Each labor court covers a number of "cantons" defined by the law (Decree No. 2008-514 of May $29^{\text {th }} 2008$ and decree No. 2014-899 of August 18 ${ }^{\text {th }}$ 2014.)

${ }^{15}$ The judges in removed labor courts were reallocated to other courts. Some 114 civil servants were working in removed labor courts: most of them were reallocated to other jurisdictions, with 26 positions being removed between 2008 and 2010 (Sénat (2012)).

${ }^{16}$ The exact criterion was to keep one labor court per "Département", and one in the geographical area of each civil court. These two geographical areas are more or less the same.
} 
The reduction of the number of courts led to a redefinition of the jurisdiction of some remaining courts. Following decree No. 2008-514, we distinguish between four types of courts:

- Courts that were removed at the end of 2008 (removed courts);

- Courts that took on the claims of the removed courts after 2008 (receiving courts). The jurisdiction of these courts was extended at the end of 2008 to cover the geographical areas of the removed courts. All future and already-opened claims from a removed court were transferred to one and only one receiving court within the same Département;

- Courts that could not be removed during the reform because they were the unique court of their Département before 2008 (non-treatable courts); and

- Courts that were not affected by the reform but that could have been selected (unaffected courts).

\subsection{Potential impacts of the reform}

The reform may affect job creation and destruction on the labor market by changing the cost of litigation to challenge dismissals. We briefly discuss here the different channels via which this reform may operate.

First, courts were more concentrated after the reform. The distance to court increased for some parties, and case delays may also rise as more cases are brought to courts whose geographical jurisdiction has been widened. Both lead to higher litigation costs. This may affect the employees' decision to open claims. Anticipating this, employers could predict lower firing costs as the likelihood of going to court falls. This could increase job destruction and creation on the labor market. However, the reverse can also come about: firing costs also increase for employers in the case of litigation, especially for small and medium-sized firms, which can make them more reluctant to hire and fire. Overall, the net theoretical effect of the reform on job creation and destruction is difficult to determine.

There are also other effects. If litigation costs increase, the parties' incentives to settle before going to court will rise. However, this can also change the required settlement amount as the outside option in case of settlement failure is more costly. Here again, the net effect on the precourt settlement (and ultimately on firing costs) is ambiguous.

The nature of claims sent to court may also be affected by the reform. As litigation costs increase, pre-court settlements may become more attractive for "simple" cases (those whose probability to win or lose at court is easy to predict). More complex claims can continue to be sent to court. They may require a number of hearings to be decided, which makes the delays at court longer. ${ }^{17}$ This will raise litigation costs for the parties.

More broadly, business creation (or destruction) can also be affected: if fewer jobs are opened, individuals may have a greater incentive to open their own business.

\footnotetext{
${ }^{17}$ The procedure for most claims is as follows. First, there is the "conciliation" stage: parties are invited to find a settled solution to their conflict. If there is no agreement they go to a ruling panel, comprising two employer lay-judges and two employee lay-judges. If the ruling panel does not make the decision (split votes inside the ruling panel, difficulties in interpreting the law etc.), then a professional judge is added to the jury (in another hearing) to decide the vote.
} 
This short discussion illustrates that it is difficult to determine the final impact of the reform on the labor market. We require empirical analysis to identify the consequences of court access on employment.

\section{Data}

\subsection{Information and units of observation}

We construct our dataset from information at the city and court levels. We first collect annual data on court activity from the website of the French Ministry of Justice, including average case duration, the number of new cases, the plaintiffs' winning rate, and the départage rate. ${ }^{18}$ Second, we collect information on the economic and demographic dynamics of French metropolitan municipalities between 2006 (two years prior to the reform) and 2012 (four years after the reform) from two French administrative sources (the Pôle Emploi and INSEE). Data on economic activity include annual information on job creation, job destruction, unemployment, and the creation of new firms. Socio-economic variables cover population characteristics (size, population of working age, and socioeconomic categories). Third, we retrieve information on the courts affected by the reform from the decree that implemented it. ${ }^{19}$ Last, we obtain the correspondence between each municipality and its associated labor court from the Ministry of Justice, and we developed a web-scraping script (Javascript) to compute the driving distance between the two. ${ }^{20}$

\subsection{Descriptive Statistics}

Using the distinction between removed, receiving, unaffected and non-treatable courts in Section 3.3, we define four categories of cities:

- Cities whose labor court was removed and that were assigned to a new labor court (removedtreated cities);

- Cities whose labor court has expanded its geographical jurisdiction (receiving-treated cities);

- Cities whose labor court was potentially removable but was not removed (unaffected cities); and

- Cities that were precluded from treatment as there was only one labor court prior to the reform in the Département (non-treatable cities).

Table 1 shows the summary statistics in 2007 of our set of variables for these four categories. As can be seen, groups are relatively heterogeneous. Removed-treated cities were the least-populated, their working-age groups were among the smallest, and they had the shortest distance to the labor court. Their labor courts were very different from the other courts: they dealt with far fewer cases and

\footnotetext{
${ }^{18}$ Départage is a special procedure in French labor courts in which a professional judge assists the lay judges in charge when they are not able to reach a majority decision. It is associated with longer delays

${ }^{19}$ Decree No. 2008-514 of May $29^{\text {th }} 2008$.

${ }^{20}$ The script was executed in June 2015. It generated individual requests to Google Maps about the driving distance between the city at stake and the municipality where the labor court is located.
} 
had low départage rates and shorter delays. These findings are consistent with the previous results in Espinosa et al. (2017) that the government targeted low-activity courts in high-unemployment areas when deciding to remove courts. On the contrary, receiving-treated cities were more similar to the untreated cities: they are comparable in terms of population, the creation of new firms, and are more similar (but still statistically different) in terms of court activity and the distance to the labor court.

Regarding labor-market conditions, cities whose distance to the labor court was changed by the reform had statistically different market conditions, with lower unemployment, less job destruction and creation and fewer new firms. This is not surprising given that these cities were significantly smaller than the cities which were not affected by the reform. To compare these subsamples, we normalize these 2007 outcomes to 100 for all cities and focus on growth rates compared to this benchmark for the remainder of the paper. Figure 1 shows the evolution of these normalized values over time. Overall, we see an increase in job destruction and unemployment, and less job creation and fewer new firms between 2006 and 2012. The global deterioration in the labor market reflects the 2008 financial crisis that greatly affected France, and whose long-term effects were still being felt in 2012. The large fall in the number of new firms between 2008 and 2009 mainly comes from a 2009 reform that created a simplified legal status for the self-employed (auto-entrepreneurs). Many people starting a business used this new status instead of creating a new firm (see Section 3.1). ${ }^{21}$

For each of the four outcomes, removed-treated and untreated cities have similar trends over the years. Cities experiencing a change in the distance to their labor court had a smaller rise in job destruction and a sharper fall in job creation compared to cities that were not targeted by the reform. Moreover, entrepreneurs appear to have created fewer firms in the areas affected by the reform compared to those in unaffected areas. On the contrary, unemployment does not seem to be related to the change in distance to the labor court.

Last, Figure 2 illustrates the distribution of the changes in distances after the reform for removaltreated cities. Workers in most of the "removed-treated cities" had to travel 25 kilometers further on average to get to their labor court. Also the change in distance is negative for some workers, so that the new labor court is closer than the older removed court. This can occur case when individuals work in cities located at the frontier of a zone. We then have the interesting situation of an exogenous shock (the reform) that rendered the distance to court either shorter, longer or unchanged.

\footnotetext{
${ }^{21}$ In other words, we focus here on the creation of firms other than self-employment. Since the creation of selfemployment status is free of charge, many were opened but without a real professional activity (or the activity was abandoned a few weeks later). Including self-employment would not then paint a realistic picture of professional occupations.
} 
Figure 1: The evolution of labor-market conditions by type of city (scores normalized to 100 in 2007).
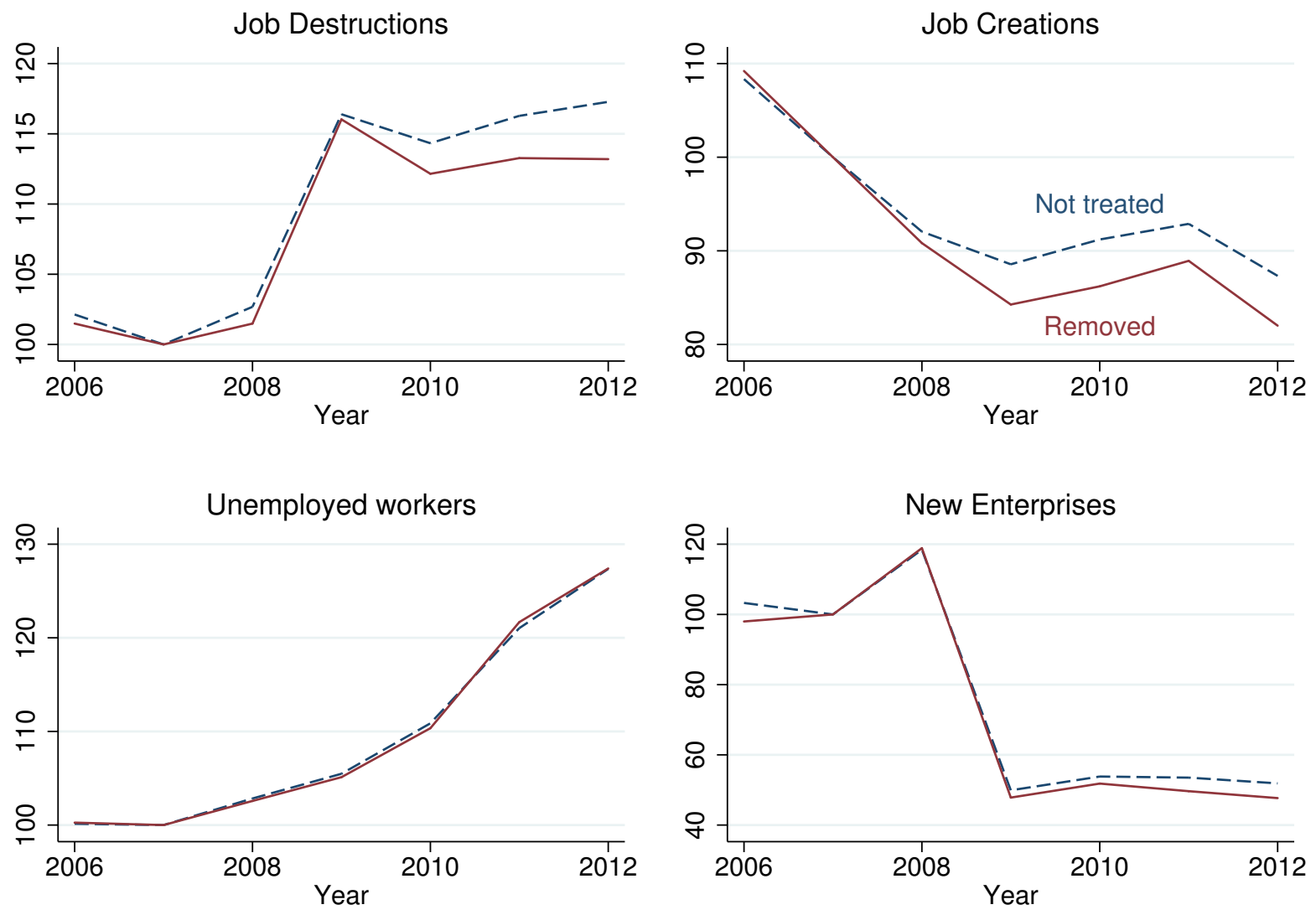

\section{Empirical Analysis}

We wish to assess the effect of the removal of labor courts on city-level economic activity. As cities were treated in different ways, we propose to estimate two kinds of effects: first the average treatment on the treated (ATT), i.e. the reform's average effect on cities where the labor court was removed, and second the effect conditional on the change in distance to the labor court.

Estimation Method The evaluation of public policies in non-randomized experiments is usually carried out either by propensity-score matching (PSM) or differences-in-differences (DiD) estimation. These methods estimate the average reaction of treated units to a particular treatment. The two techniques differ, however, in their assumptions about reaction functions and treatment assignment.

The main assumption behind DiD is that treated and non-treated units would have had similar trends were the treated units not to have been treated (the Common Trend Assumption, CTA). They further assume that treatment does not produce any general-equilibrium effects (the Stable Unit 
Figure 2: The distribution of changes in distance after the reform for removed cities.

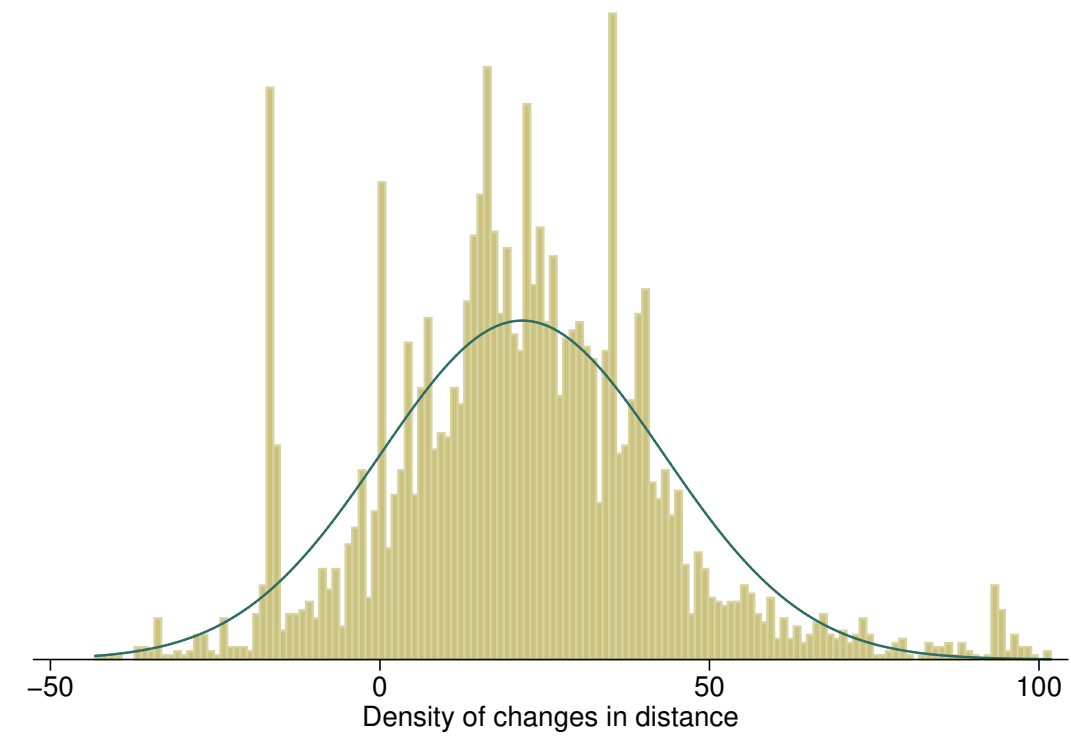

Treatment Value Assumption, SUTVA). If these two assumptions hold, DiD estimation successfully assesses the treatment effect by comparing the change over time between the treated and non-treated units once the treatment is introduced.

Alternatively, PSM estimation relies on two assumptions. First, the Conditional Independence Assumption (CIA) requires that a treated unit would have had the same outcome as non-treated units were it not to have been treated, conditional on the observables. This assumption ensures that the outcomes of similar untreated units can be used as counterfactuals for the treated units. DiD estimation makes a stronger assumption since they assume that both treated and non-treated units have the same reaction function (un)conditional on the observables (depending on whether the $\mathrm{DiD}$ are regression-adjusted). The second assumption, called the Common Support Assumption, states that units used to estimate the ATT should all have a positive probability of being treated and untreated.

Regarding the 2008 reform, Espinosa et al. (2017) have shown that the removal decisions were not random. ${ }^{22}$ Nevertheless, the graphical discussion of the outcome variables in the previous section suggests that the CTA is likely to hold: the changes between 2006 and 2007 were similar in the treated and control groups.

We thus proceed in two steps. We first estimate a DiD model including the treatment effect together with covariates that might also affect the outcome considered (regression adjustment: see Rosenbaum and Rubin (1983); Morgan and Harding (2006); Marcus (2014)). Given this first set of results, we discuss the likelihood of the CTA. Second, we use matching methods on the trends of the outcomes to generate control and treated samples that had common trends prior to the reform.

\footnotetext{
${ }^{22}$ Removed courts dealt with fewer cases and were closer to other labor courts. In Appendix 3 , we present a few elements showing that it was indeed the case, and, more importantly, that these decisions were independent from the labor market situation.
} 
We show that the CTA is more likely to hold once the correction is applied, and then discuss the new set of results.

\subsection{Differences-in-Differences}

\subsubsection{Method}

We first exploit the panel structure of the data to estimate the reform's effects in a differencesin-differences framework with regression adjustment. To estimate the ATT we use the following specification on the sample including cities that could have been affected by the reform and cities that were affected by the reform. The general specification is:

$$
y_{i t}=\beta X_{i t}+\mu_{t}+\alpha_{i}+\sum_{s \neq 2007} \phi_{s}\left(D_{i} \times \mathbb{1}_{s=t}\right)+u_{i t}
$$

where $X$ is the set of covariates discussed in the descriptive statistics, ${ }^{23} \mu_{t}$ is the set of year fixedeffects, $\alpha_{i}$ is the set of city fixed-effects, and $u_{i t}$ is a random term. The variable $D_{i}$ is 1 for removed treated cities and 0 for non-treated cities (excluding non-treatable courts). ${ }^{24}$ The set of coefficients $\phi=\left\{\phi_{2006}, \phi_{2008}, \phi_{2009}, \phi_{2010}, \phi_{2011}, \phi_{2012}\right\}$ represents the ATT for each year. The reform was discussed, voted and ratified in 2008. We deal with anticipation effects by taking 2007 as the reference year. An insignificant estimate of $\phi_{2006}$ implies that the treated and untreated cities had similar trends between 2006 and 2007, making the CTA more likely to hold. The outcomes $y_{i t}$ considered here are the normalized scores of job creation, job destruction, unemployment and new firm creation introduced in Section 4.2. Given the normalization, the marginal effects are the differences in growth rates between the treated and non-treated cities between 2007 and year $t$.

Second, we explore the reform's effect conditional on the change in distance to the new labor court. To do so, we estimate the above model for two subsets of treated cities: those for which the distance to the labor court rose $\left(\phi_{I}\right)$ and those for which it fell $\left(\phi_{D}\right)$.

\subsubsection{Results}

Table 2 in the Appendix shows the estimated coefficients from equation 1. Cities that were affected by the reform had significantly lower job destruction, job creation and creation of new firms. However, this first estimation also shows a significantly higher trend of firm creation in treated cities prior to the reform $\left(\phi_{2006}>0\right)$. This casts some doubt on the validity of the CTA for firm creation. On the one hand, it might be that the estimated negative coefficients associated with the reform after 2008 underestimate the impact: treated cities benefited from a higher trend in firm creation that was so strongly affected that it turned negative after the reform. On the other hand, it is possible that the effect is overestimated: the boom in firm creation between 2006 and

\footnotetext{
${ }^{23}$ We exclude the duration of cases at the court level since this is missing in 2008 . The results including this variable are qualitatively equivalent and are presented as a robustness check.

${ }^{24}$ We change the composition of the control group by including the non-treatable cities as a robustness check: see below.
} 
2007 would have potentially been offset by a negative trend after 2007, even in the absence of reform.

Second, we estimate our econometric model separately for cities that experienced rises and falls in distance to the labor court. The results appear in Tables 3 and 4 respectively, and are depicted in Figures 3 and 4.

A number of comments can be made in the light of this new set of estimates. For cities with a rise in distance to the labor court, we have similar but stronger effects compared to the average effect over the entire set of treated cities: job creation, job destruction and new firm creation all fall significantly compared to cities that were unaffected by the reform. Job destruction between 2007 and 2012 was about 4 percentage points (pp) lower in cities with an increased distance to the labor court; the analogous figures for job creation and the creation of new firms are $4.6 \mathrm{pp}$ and $6.3 \mathrm{pp}$ respectively. In other words, labor-market functioning there was significantly degraded by the reform. Employers were less likely to hire new employees, fire existing employees and create new firms. The overall effect on unemployment is not statistically significant, but the coefficient is positive. For cities with a fall in the distance to the labor court, the results are opposite but insignificant (i.e. higher job destruction and creation). The lack of significance might reflect two technical considerations, as Figure 2 shows. First, only relatively few cities experienced a fall in distance (108) compared to the number with a rise $(1,093)$, which reduces statistical power. Second, the average fall in distance is relatively small $(-11.3 \mathrm{~km})$ compared to the average increase in distance $(+25.7 \mathrm{~km})$. The smaller sample size and weaker treatment are likely behind the lack of significance for cities with a fall in distance.

Robustness We explore the sensitivity of our findings to changes in the control group and estimation method. We first re-estimate the above specifications including the untreatable cities in the control group. The results in Tables A1 to A3 in the Online Appendix are similar.

Second, we reconsider the above specifications for the two types of treated cities using a multilevel mixed effects model. We introduce random effects at the city and court $\times$ year level $\left(\phi_{c(i), t}\right)$. The vector of covariates $X_{i t}$ is decomposed into covariates that are defined at the city level $\left(X_{1, i t}\right)$ and those that are defined at the court level $\left(X_{2, c(i) t}\right)$ The multilevel model is:

$$
\begin{aligned}
y_{i t} & =\beta X_{1, i t}+\mu_{t}+\alpha_{i}+\phi_{c(i), t}+\sum_{s \neq 2007} \phi_{s}\left(D_{i} \times \mathbb{1}_{s=t}\right)+u_{i t} \\
\alpha_{i} & =\gamma_{0}+e_{i} \\
\phi_{c(i), t} & =\lambda X_{2, c(i) t}+\epsilon_{c(i), t}
\end{aligned}
$$

where $\lambda$ includes an intercept, $u_{i t}$ is a random term at the city $\times$ year level, $e_{i}$ a random term at the city level, and $\epsilon_{c(i), t}$ a random term at the court $\times$ year level.

The estimates from this model for the two separate samples (e.g. rising or falling distance) appear in Tables A4 and A5 in the Online Appendix and are similar to those shown previously, i.e. a significant fall in job destruction, job creation and new firms in cities that had a rise in distance to the labor court, and insignificant rises in job destruction and creation for cities with a smaller distance. 
CTA Two variables may be suspected of violating the Common Trend Assumption in the above regressions. First, the number of new firms seems to have grown faster between 2006 and 2007 in treated compared to control cities (Table 2). This effect is mainly due to cities whose distance to the labor court increased (Table 3). Second, unemployment rose significantly more in cities where the distance to the labor court fell compared to the control group (Table 4). We now turn to matching methods to correct the control group sample and ensure the validity of the Common Trend Assumption.

Figure 3: The marginal effects of the reform in cities that experienced a rise in the distance to the labor court. (Differences-in-differences)
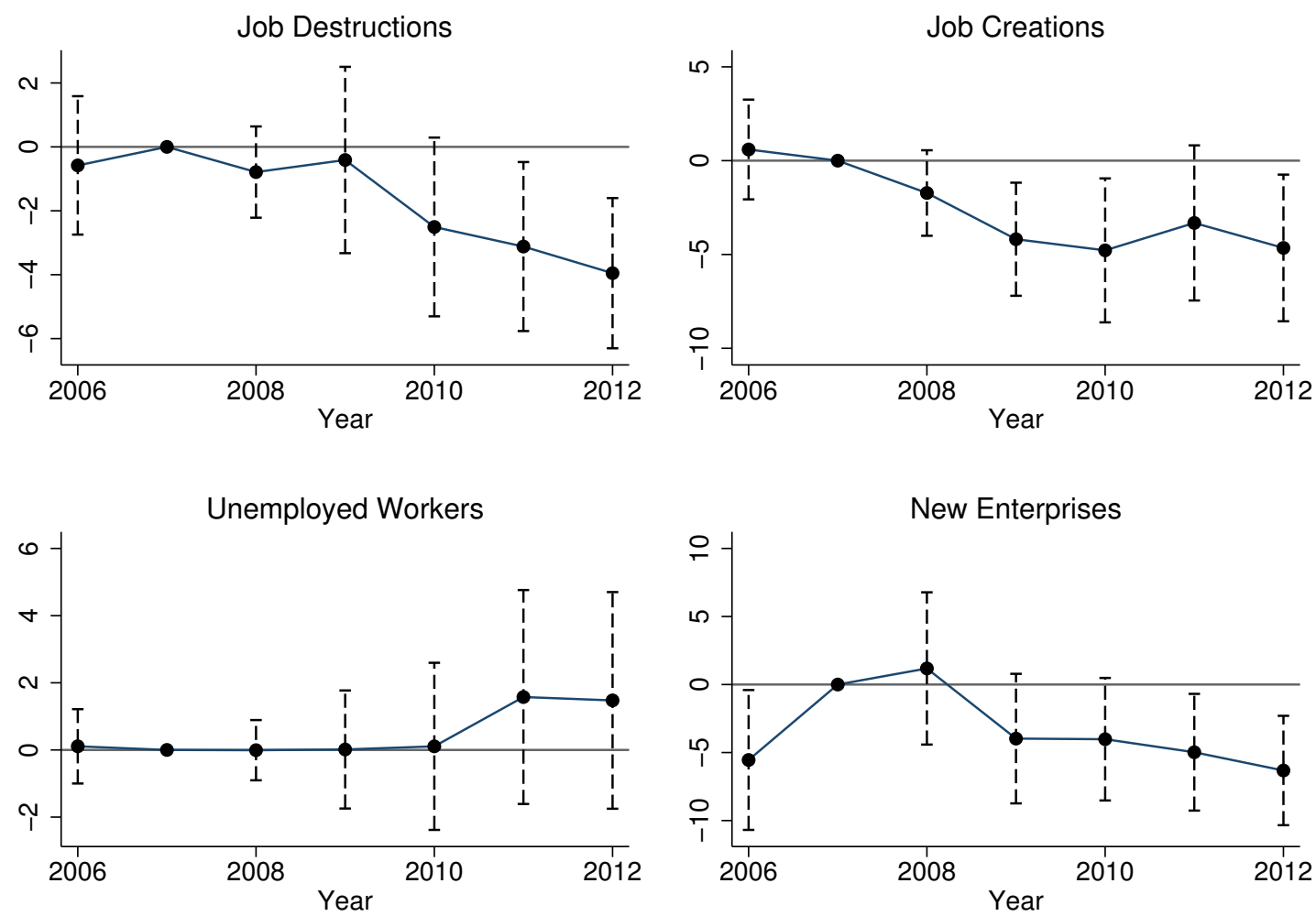

Note: The confidence intervals are at the $95 \%$ confidence level. The outcomes are normalized to 100 in 2007 . These are regression-adjusted differences-in-differences, with standard errors clustered at the court level.

\subsection{Conditional Differences-in-Differences}

The results above reveal the potential violation of CTA is for some of our outcomes. We therefore propose to correct our estimations by weighting the sample control to produce a sample of untreated cities with a pre-reform trend similar to that in treated cities. We first estimate a propensity score and then run the above regressions with the weights derived from a matching algorithm.

\subsubsection{Matching}

To obtain similar pre-reform trends, we estimate the propensity score at the city level, i.e. the probability that a city have its associated court removed, based on the change between 2006 and 
Figure 4: The marginal effects of the reform in cities that experienced a fall in the distance to the labor court. (Differences-in-differences)
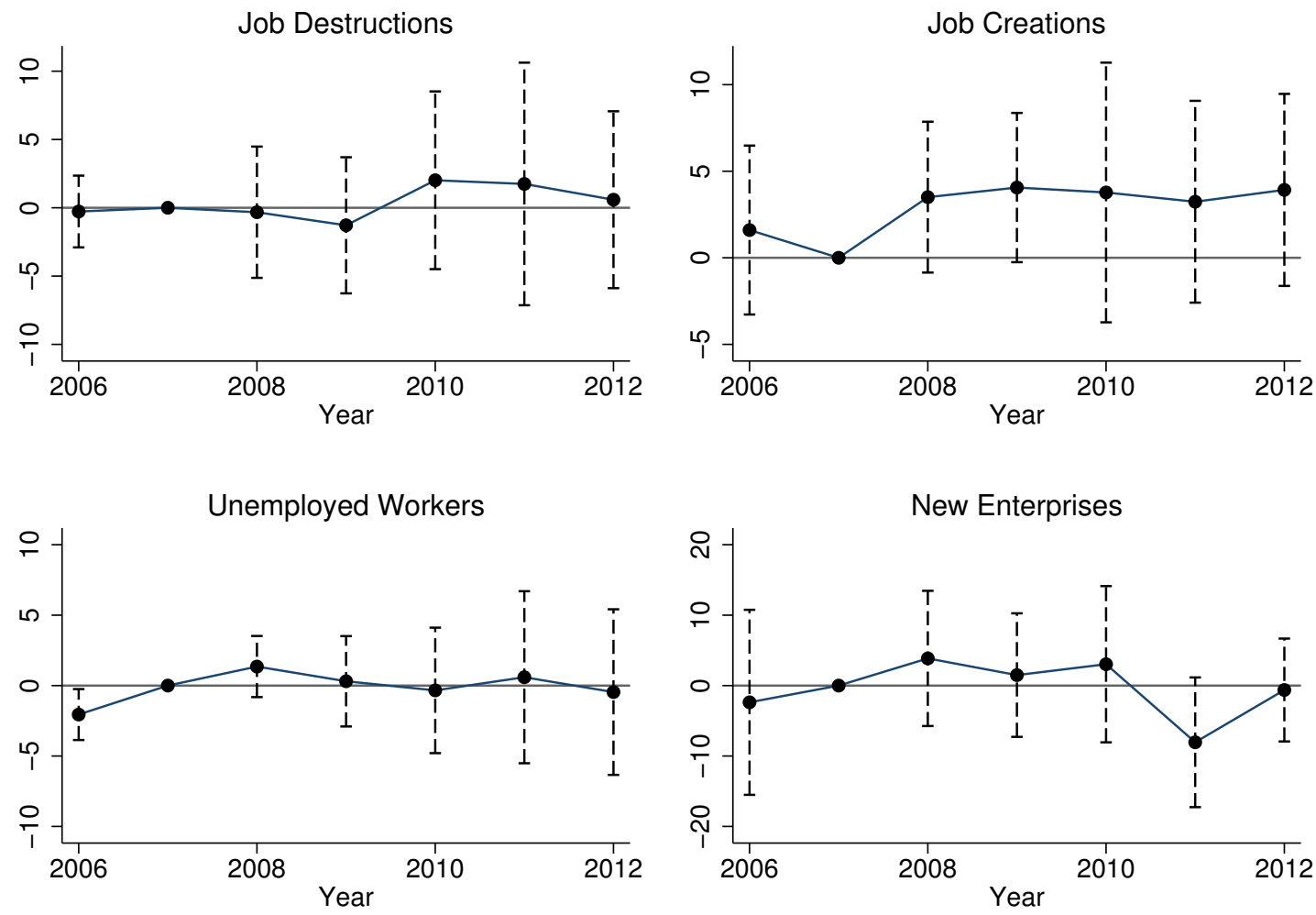

Note: The confidence intervals are at the $95 \%$ confidence level. The outcomes are normalized to 100 in 2007. These are regression-adjusted differences-in-differences, with standard errors clustered at the court level.

2007 of the variables of interest (job creation, job destruction, unemployment and new firms). ${ }^{25}$ This matching on pre-reform trends aims to correct for any pre-trend differences in the DiD estimation. The removal decision is defined as:

$$
\operatorname{removal}_{i}^{*}=\gamma \Delta Y_{i}+u_{i}
$$

where removal* is the latent variable associated with removal (which is set to 1 if the labor court associated with city $i$ was removed and 0 if not). $\Delta Y_{i}$ are the changes in labor-market outcomes between 2006 and 2007.

We consider a number of matching algorithms to calculate weights based on the propensity score from the above equation. We consider in turn the Epanechnikov Kernel (EK), Gaussian Kernel (GK), and three-nearest neighbor algorithm (N3). We further use a fourth matching algorithm, the Covariate Balancing Propensity Score (CBPS) method. This technique relies on GMM estimation, and jointly estimates the propensity score and the associated weights so as to minimize the

\footnotetext{
${ }^{25}$ Matching is effected on the changes between 2006 and 2007 rather than between 2007 and 2008 to avoid potential anticipation effects, as the reform was discussed, voted and ratified in 2008.
} 
ex-post bias between the treated and control groups.

Comparing Matching Techniques Table 5 presents the average standardized bias (ASB) in each matching model. It also shows, for each estimation, the number of variables with standardized bias above $5 \%{ }^{26}$ We present two sets of results: on the left-hand side we show the ASB for the matching procedure in cities whose distance to the labor court rose; the right-hand side shows the analogous results for cities whose distance fell.

First of all, the data reveal relatively little heterogeneity in the pre-reform trends: the ASB figure is below the $5 \%$ threshold for cities with increased distance and below the $10 \%$ threshold for cities with lower distance. We note however that half of the labor-market outcomes can be considered as biased, i.e. as having statistically different trends between 2006 and 2007. This justifies the use of matching to produce a control group with pre-reform trends similar to those in treated cities.

Second, regarding the matching algorithm, the CBPS seems to be the most efficient way of reducing the $\mathrm{ASB}$, with the values of the latter falling from 4.44 (resp. 7.25) in the unmatched sample to 0.06 (resp. 0.03) in the matched sample for cities with greater (lower) distance. The CBPS algorithm also minimizes the number of biased variables. The Nearest Neighbor Algorithm (N3) is the second-best matching algorithm in terms of the ASB.

\subsubsection{The Results of Conditional Differences-in-differences}

We now estimate equation 1 with the weights from the CBPS matching algorithm. ${ }^{27}$ Given that the reform seems to have had different effects according to the change in distance (higher or lower), we estimate an ATT separately by type of affected city.

Table 6 and Figure 5 display the results of this new estimation for cities with greater distance to the labor court. We first note a substantial improvement in the CTA, which now holds for all outcomes. Second, this new set of results confirms the original findings: cities with greater distance to the labor court suffered from lower job destruction (about -3.8 percentage points between 2007 and 2012), job creation (-5.8 pp) and new-firm creation (-5.4 pp).

The results for cities with a fall in distance (Table 7 and Figure 6) reveal no significant effects of the reform. However, as in the $\mathrm{DiD}$ framework, the results by city type are mirror images of each other, with increased job creation and destruction in this second set of cities. Here again, insignificance likely reflects the less-pronounced treatment in these cities, and the relatively small number of cities with lower distance.

Robustness We explore additional specifications to test the robustness of the above results. We first include non-treatable cities in the control group, i.e. cities whose labor court could not have been removed by the reform (Online Appendix, Tables A7 and A8). Second, we add the average duration of terminated cases in the associated labor court to the control variables (Online Appendix, Tables A9 and A10). For this latter, we exclude observations in 2008 for which the Ministry of

\footnotetext{
${ }^{26}$ The $5 \%$ threshold is usually used in the literature following the original paper of Heckman et al. (1998).

${ }^{27}$ We use the Stata $x t r e g$ package to estimate the model with weights, clustering observations at the pre-reform labor court level.
} 
Justice data has many missing values. ${ }^{28}$ Third, we estimate the above models using the second-best matching algorithm in terms of bias reduction (N3: Online Appendix, Tables A11 and A12) Finally, we use the CBPS scores with the multilevel mixed-effects model with the same specification as in the previous section (Online Appendix, Tables A13 and A14). All of these alternative estimations yield the same results as in the main text above: the reform had no significant effect on cities with lower distance to the labor court, but a negative effect on job creation, job destruction and new-firm creation for cities where this distance rose.

Figure 5: Marginal effects of the reform for cities that experienced a rise in the distance to the labor court. (Conditional Differences-in-differences)
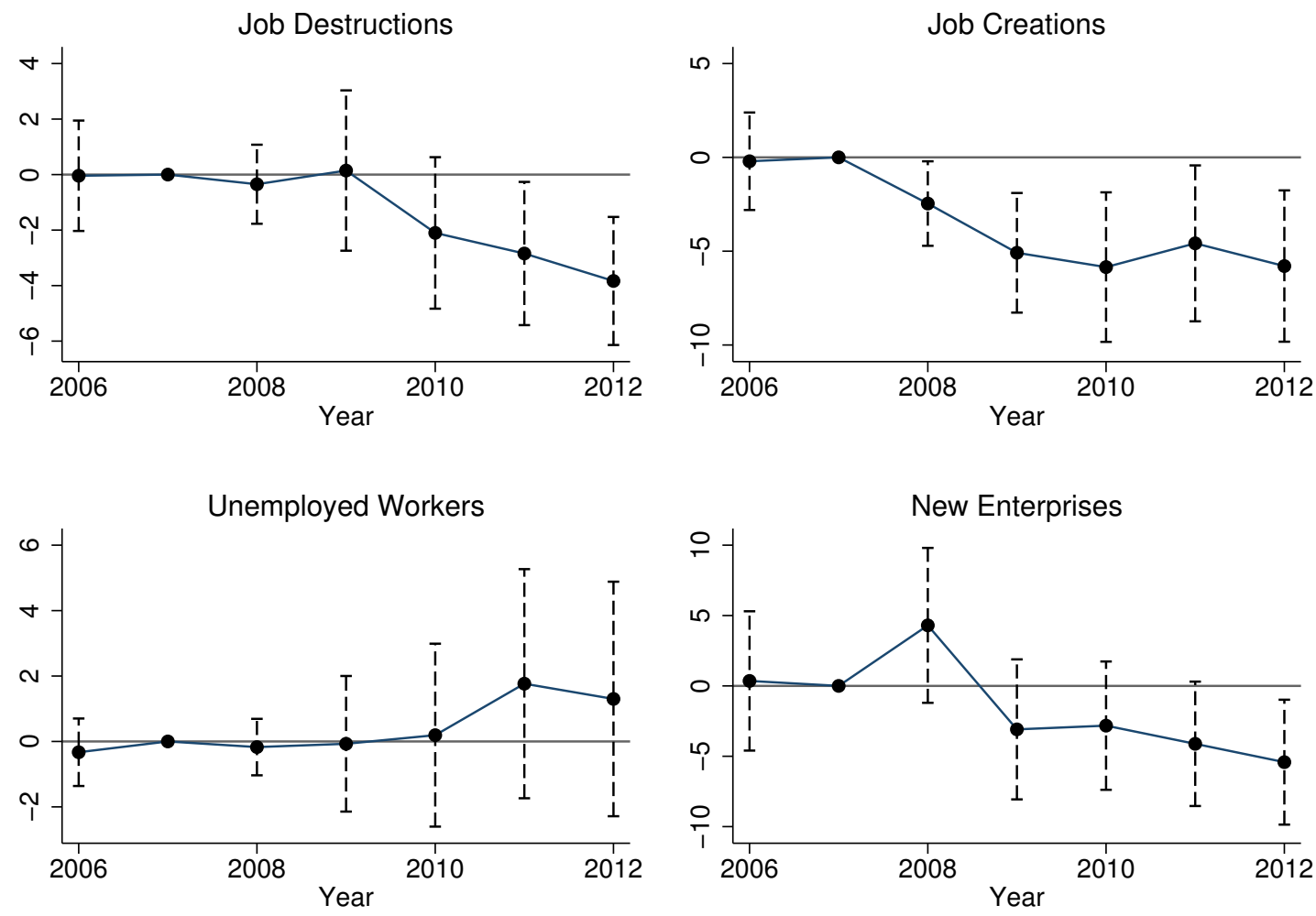

Note: The confidence intervals are at the $95 \%$ confidence level. The outcomes are normalized to 100 in 2007 . These are regression-adjusted differences-in-differences, with standard errors clustered at the court level.

\subsection{Linear Impact of the Distance}

The above sections have presented the overall impact of the reform for two groups of cities: those that experienced an increased in distance to their labor courts, and those that experienced a fall. We now propose to estimate a linear specification, which seeks to estimate the impact of one additional kilometer to the associated labor court. We assume here that distance has a linear impact on the labor market outcomes, and that an increase and a fall of distance have similar but opposite effects. The associated specification is:

\footnotetext{
${ }^{28}$ We prefer to drop data in 2008 rather than only the missing values, as the estimations are carried out using weights, which are calculated using the entire sample. Dropping one year for every observation does not affect the validity of the matching process.
} 
Figure 6: Marginal effects of the reform for cities that experienced a fall in the distance to the labor court. (Conditional Differences-in-differences)
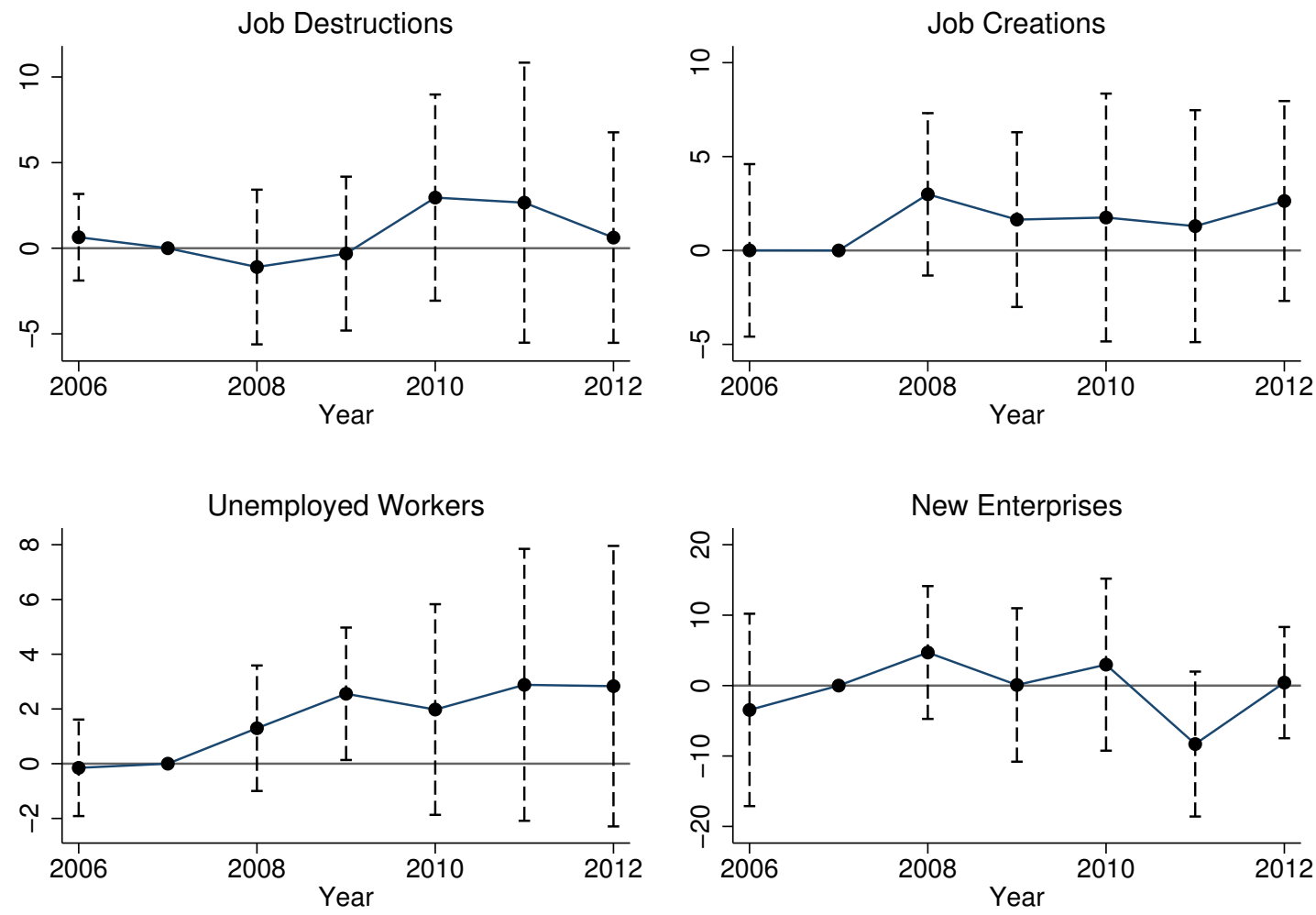

Note: The confidence intervals are at the 95\% confidence level. The outcomes are normalized to 100 in 2007. These are regression-adjusted differences-in-differences, with standard errors clustered at the court level.

$$
y_{i t}=\beta X_{i t}+\mu_{t}+\alpha_{i}+\sum_{s \neq 2007} \phi_{s} \mathbb{1}_{s=t} \Delta_{i}+u_{i t}
$$

where $\Delta_{i}$ represents the change of distance to the associated labor court. It is equal to zero for non-treated cities for all periods, and to the change of the distance for treated cities due to the reform.

This specification allows us to estimate the impact of one additional kilometer for each year after the reform. Results of this estimation are displayed in tables 8 (without matching correction) and 9 (with matching correction). First of all, one can observe that the coefficient associated to the reform change of distance is significant for New Enterprises in 2006 in absence of matching correction (table 8). This suggests that, prior to the reform, cities in the sample differ in the number of New Entreprises according to the future change in distance. The matching correction successfully erases these differences, and no effect is significant in 2006 once we use a weighted specification (table 9).

Results with the matching correction are graphically displayed on figure 7. As one can see, an increase of distance to the labor court significantly decreases job destructions, job creations and, eventually, the firm creations in the subsequent years. For an increase of 10 kilometers, we 
estimate that the growth rate between 2006 and 2012 was lower by 0.8 percentage points for job destructions, by 1.5 percentage points for job creations, and by 1.8 percentage points for new firms. Results including non-treatable cities, displayed in the Online Appendix (tables A15 and A16), lead to similar observations.

Figure 7: Marginal effects of an increase of one kilometer in the distance to the labor court on affected cities. (Linear specification, with matching-correction)
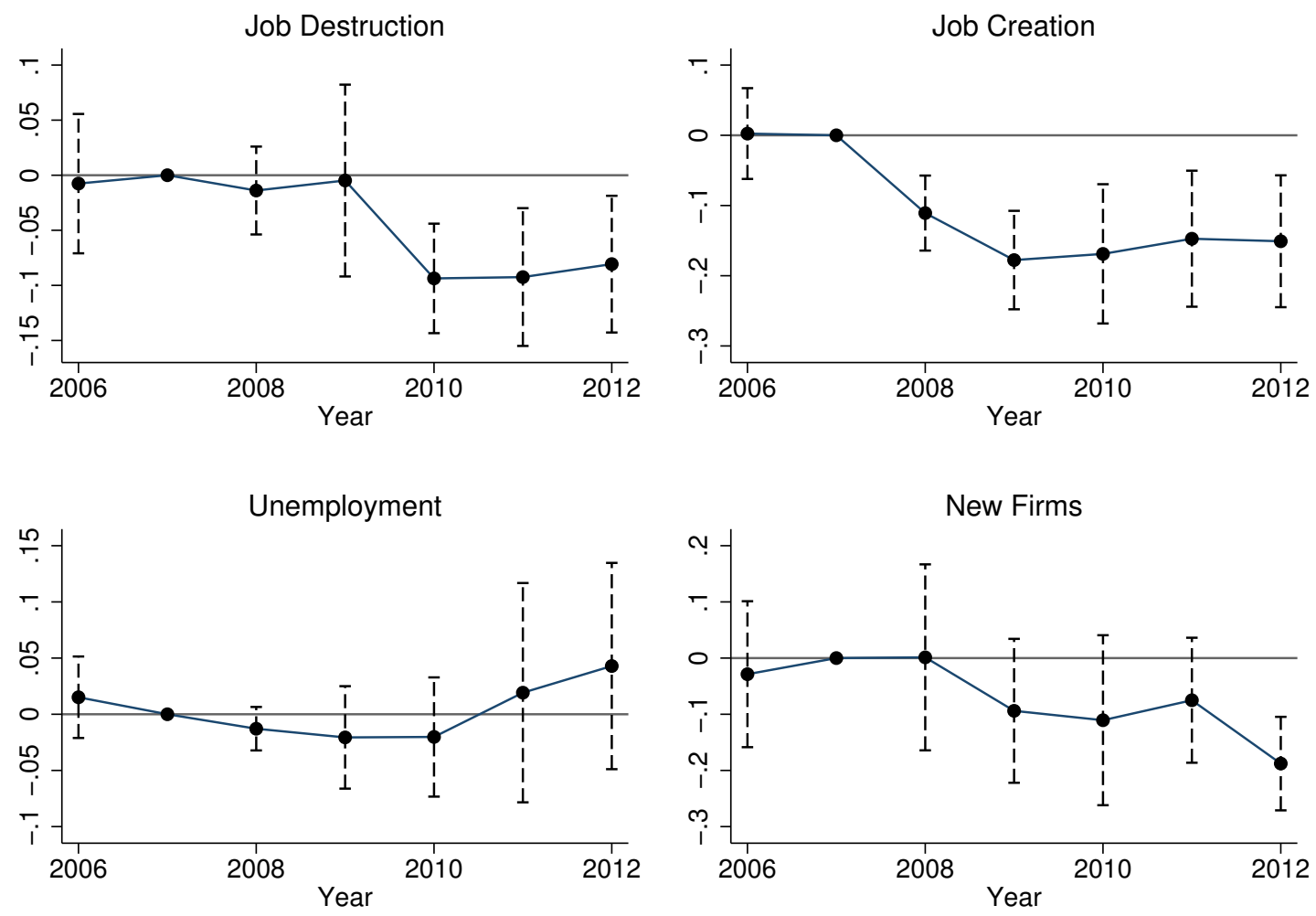

Note: The confidence intervals are at the $95 \%$ confidence level. The outcomes are normalized to 100 in 2007. Standard errors clustered at the court level.

\subsection{Limitations}

Our empirical investigation attempted to address most of the challenges public-policy evaluations generally face. However, two main issues were not tackled here, as the necessary econometric tools have not yet been developed. First, we are aware that the estimation of the propensity score might produce measurement errors, which are not taken into account here. Abadie and Imbens (2016) show that propensity-score estimation affects the large-sample distribution of the matching estimator. Their contribution is however to date limited to the ATT without regression adjustment. Further developments (especially in regression adjustment and conditional DiD) are required to correct for the potential biases in our case. Second, the matching algorithm might generate a need for additional clustering between matched units. Abadie and Spiess (2016) derive results for the K-nearest neighbors matching technique without replacement. This is the simplest matching algorithm, as the clusters are exclusive, and we have no doubt that these results will be extended 
to more complex matching algorithms in the coming years.

\section{Conclusion and Discussion}

Public decision-makers usually face a trade-off between two (opposite) policy goals: limiting public expenditure and ensuring the good functioning of the labor market. In recent years, this dual optimization problem has received increasing attention, with rising concern about national debt and the sharp increase in unemployment in developed countries. In June 2016, the IMF stated: "[The risks of stagnation] are particularly worrisome for the euro area, given the high level of unemployment and public and private debt in some member countries". ${ }^{29}$ Public authorities have thus devoted particular attention to reductions in public expenditure that would have the smallest effect on the economy and, in particular, the labor market.

One popular proposal among public decision-makers has been to rationalize public administration in order to reduce its costs. A number of countries have thus sought to reduce their number of (labor) courts. However, the impact of such reforms on the labor market has received little attention from public authorities given the lack of associated empirical evidence.

Our paper is the first piece of empirical analysis to assess the impact of labor-court access on the labor market. We do so by exploiting the 2008 French reform that removed one quarter of the labor courts in France. We distinguish between two types of cities that were affected by the reform: those with increased and reduced distance to the labor court. The estimation of (conditional) differences-in-differences reveals that greater distance is associated with worse-performing labor markets: lower job destruction (-4 percentage points), job creation ( $-4.6 \mathrm{pp}$ ) and new-firm creation (-6.3 pp) between 2006 and 2012 for cities with a greater distance compared to unaffected cities. We also find opposite-signed but insignificant effects in cities where the distance to the labor court fell (i.e. higher job destruction and creation).

These results cast some doubt on the net benefit of such reforms. There are multiple effects on both public spending and economic activity. Labor courts are a key institution for the enforcement of labor contracts, and access to them affects economic behavior. Our results suggest that greater distance brings about higher costs. Our interpretation is that these latter can be particularly heavy for small-sized firms, which represent the majority of firms in France, as described in Section 3.1. Employers in these firms are particularly affected by the changes in litigation costs resulting from court accessibility. The regions that were affected by the reform already had weaker labor markets prior to the reform. Their economic network was mainly composed of smaller firms: these employers are particularly affected by the changes in litigation costs due to court access. The costs can be both direct (transportation costs) and indirect (opportunity cost of going to court). As the presence of both parties is mandatory at certain stages of the procedure (even though the party can be represented for others) the repeated costs of greater distance might translate into a substantial burden for employers. Overall, our estimations show that the increased burden for both employees and employers leads to worse labor-market performance.

\footnotetext{
${ }^{29}$ https://www.imf .org/external/pubs/ft/fandd/2016/06/pdf/lin.pdf.
} 


\section{Acknowledgements}

We are grateful to Pierre Cahuc, Laurent Davezies, Xavier d'Haultfoeuille and Francis Kramarz for discussions which led to improvements in the paper. We also thank participants at the CREST seminar, the Law \& Economics Workshop (Florence, 2016), the LAGV conference (Aix-en-Provence, 2016), the EEA conference (Geneva, 2016), the AFSE conference (Nancy, 2016) and the TEPP winter school (Aussois, 2016). 


\section{References}

Abadie, A. and Imbens, G. W. (2016). Matching on the Estimated Propensity Score. Econometrica, 84(2):781-807.

Abadie, A. and Spiess, J. (2016). Robust Post-Matching Inference. Working Paper.

Acemoglu, D. and Johnson, S. (2005). Unbundling Institutions. Journal of Political Economy, 113(5):949-995.

Bauer, T. K., Bender, S., and Bonin, H. (2007). Dismissal Protection and Worker Flows in Small Establishments. Economica, 74(296):804-821.

Behaghel, L., Crépon, B., and Sédillot, B. (2008). The perverse effects of partial employment protection reform: The case of French older workers. Journal of Public Economics, 92(3-4):696721.

Chappe, N. and Obidzinski, M. (2014). The Impact of the Number of Courts on the Demand for Trials. International Review of Law and Economics, 37:121-125.

Chemin, M. (2009). The impact of the judiciary on entrepreneurship: Evaluation of Pakistan's Access to Justice Programme. Journal of Public Economics, 93(1-2):114-125.

Chemin, M. (2012). Does Court Speed Shape Economic Activity? Evidence from a Court Reform in India. Journal of Law, Economics and Organization, 28(3):460-485.

Cour des comptes (2015). Rapport public annuel 2015. Technical report.

Djankov, S., La Porta, R., López-de Silanes, F., and Shleifer, A. (2003). Courts. The Quarterly Journal of Economics, 118(2):453-517.

ENCJ (2012). Judicial Reform in Europe, 2011-2012. Technical report.

Espinosa, R., Desrieux, C., and Wan, H. (2017). Fewer Courts, less Justice? Evidence from the 2008 French Reform of Labour Courts. European Journal of Law and Economics, forthcoming.

Fraisse, H., Kramarz, F., and Prost, C. (2014). Labor disputes and labor flows. Industrial and Labor Relations Review, forthcoming.

Garibaldi, P., Borgarello, A., and Pacelli, L. (2003). Employment protection legislation and the size of firms: A close look at the Italian case . Giornale degli Economisti e Annali di Economia, 63(1):33-68.

Gianfreda, G. and Vallanti, G. (2015). Labour Courts delays and the composition of employment: Is labour encouraged or endangered by institutions? Working papers luisslab, Dipartimento di Economia e Finanza, LUISS Guido Carli.

Gomes, C. (2007). The Transformation of the Portuguese Judicial Organization: between Efficiency and Democracy. Utrecht Law Review, 3(1):101-111.

Guilloneau, M. and Serverin, E. (2015). Les litiges individuels du travail de 2004 à 2013: des actions moins nombreuses mais toujours plus contentieuses. Technical Report 135, Infostat, Ministère de la Justice. 
Heckman, J. J., Ichimura, H., and Todd, P. (1998). Matching As An Econometric Evaluation Estimator. Review of Economic Studies, 65:261-294.

Hernanz, V., Jimeno, J., and Kugler, A. (2005). Employment consequences of restrictive permanent contracts: Evidence from Spanish labour market reforms. CEPR Discussion Paper No. 3724.

Kugler, A. and Pica, G. (2008). Effects of employment protection on worker and job flows: Evidence from the 1990 Italian reform. Labour Economics, 15(1):78-95.

Kugler, A. D. and Saint-Paul, G. (2004). How Do Firing Costs Affect Worker Flows in a World with Adverse Selection? Journal of Labor Economics, 22(3):553-584.

Le Barbanchon, T. and Malherbet, F. (2013). An anatomy of the French labor market. Technical Report Employment Working paper 142, International Labour Office.

Mak, E. (2008). Balancing Territoriality and Functionality; Specialization as a Tool for Reforming Jurisdiction in the Netherlands, France and Germany. International Journal for Court Administration, 1(2):2-9.

Marcus, J. (2014). Does Job Loss Make You Smoke and Gain Weight? Economica, 81(324):626-648.

Ministère de la Justice (2011). La réforme de la carte Judiciaire. Technical report, L'Actu Justice.

Morgan, S. L. and Harding, D. J. (2006). Matching estimators of causal effects: Prospects and pitfalls in theory and practice. Sociological Methods \& Research, 35(1):3-60.

Rosenbaum, P. and Rubin, D. (1983). The Central Role of the Propensity Score in Observational Studies for Causal Effects. Biometrika, 70:41-55.

Schivardi, F. and Torrini, R. (2008). Identifying the effects of firing restrictions through sizecontingent differences in regulation. Labour Economics, 15(3):482-511.

Sénat (2012). La réforme de la carte judiciaire: une occasion manquée. Technical report, Rapport d'Information de Mme Nicole Borvo Cohen-Seat et M. Yves Détraigne, fait au nom de la commission des lois.

Tresor-Eco (2014). Le traitement des litiges en droit du travail : constats et perspectives economiques. Technical Report 137, Lettre du Minsitere de l'Economie, de l'Industrie et du Numerique.

Van Djik, F. and Horatius, D. (2013). Judiciary in Times of Scarcity: Retrenchment and Reform. International Journal for Court Administration, 5(1):15-24.

Visaria, S. (2009). Legal Reform and Loan Repayment: The Microeconomic Impact of Debt Recovery Tribunals in India. American Economic Journal: Applied Economics, 1(3):59-81.

von Below, D. and Thoursie, P. S. (2010). Last in, first out?: Estimating the effect of seniority rules in Sweden. Labour Economics, 17(6):987-997.

Von Lilienfeld-Toal, U., Mookherjee, D., and Visaria, S. (2012). The Distributive Impact of Reforms in Credit Enforcement: Evidence From Indian Debt Recovery Tribunals. Econometrica, 80(2):497-558.

World Bank (2011). Improving the Performance of Justice Institutions. Technical report. 


\section{Appendix 1: Maps of Judicial System}

Figure 8: French courts before the reform and removals during the reform

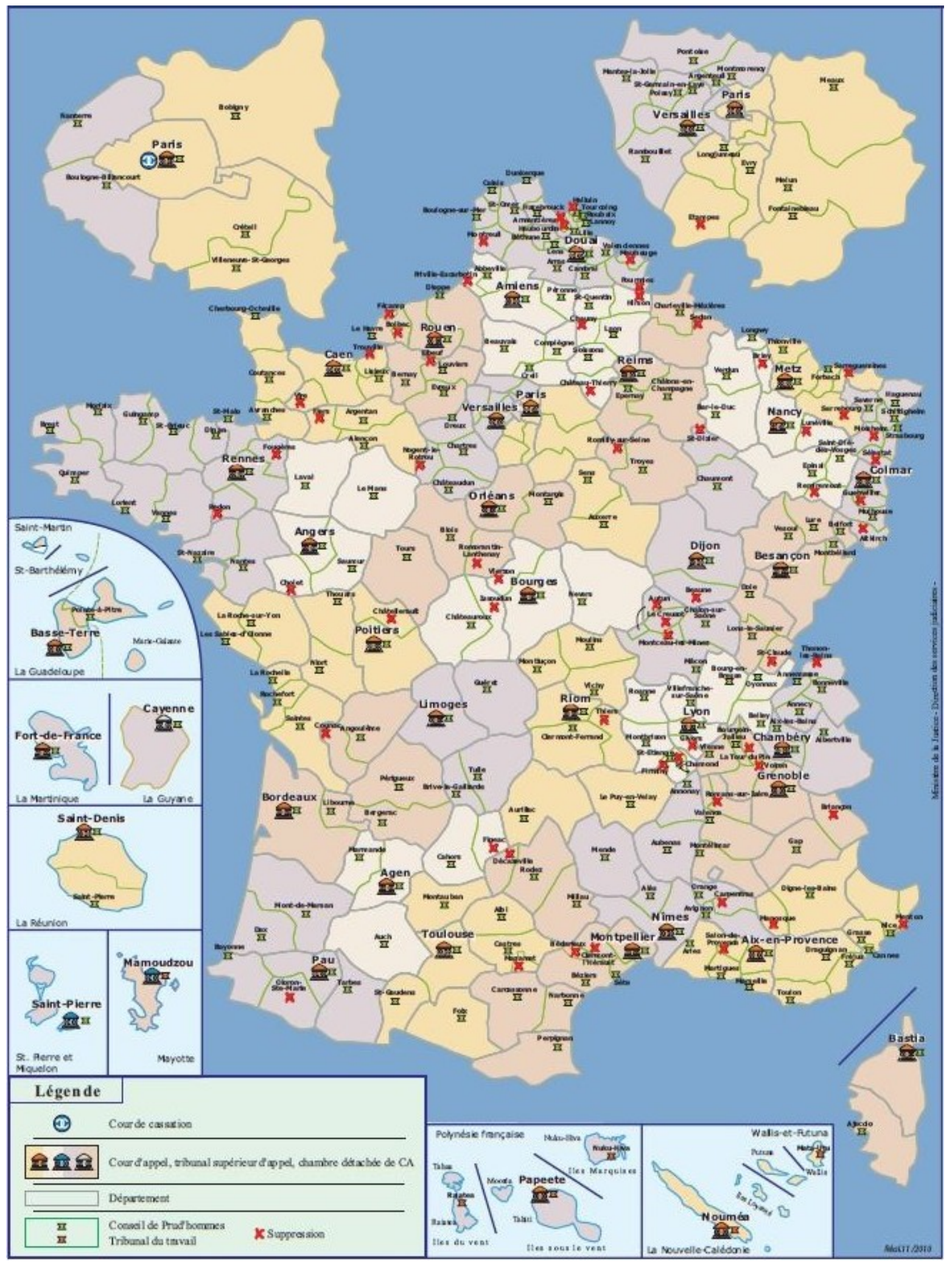


Figure 9: French courts after the reform

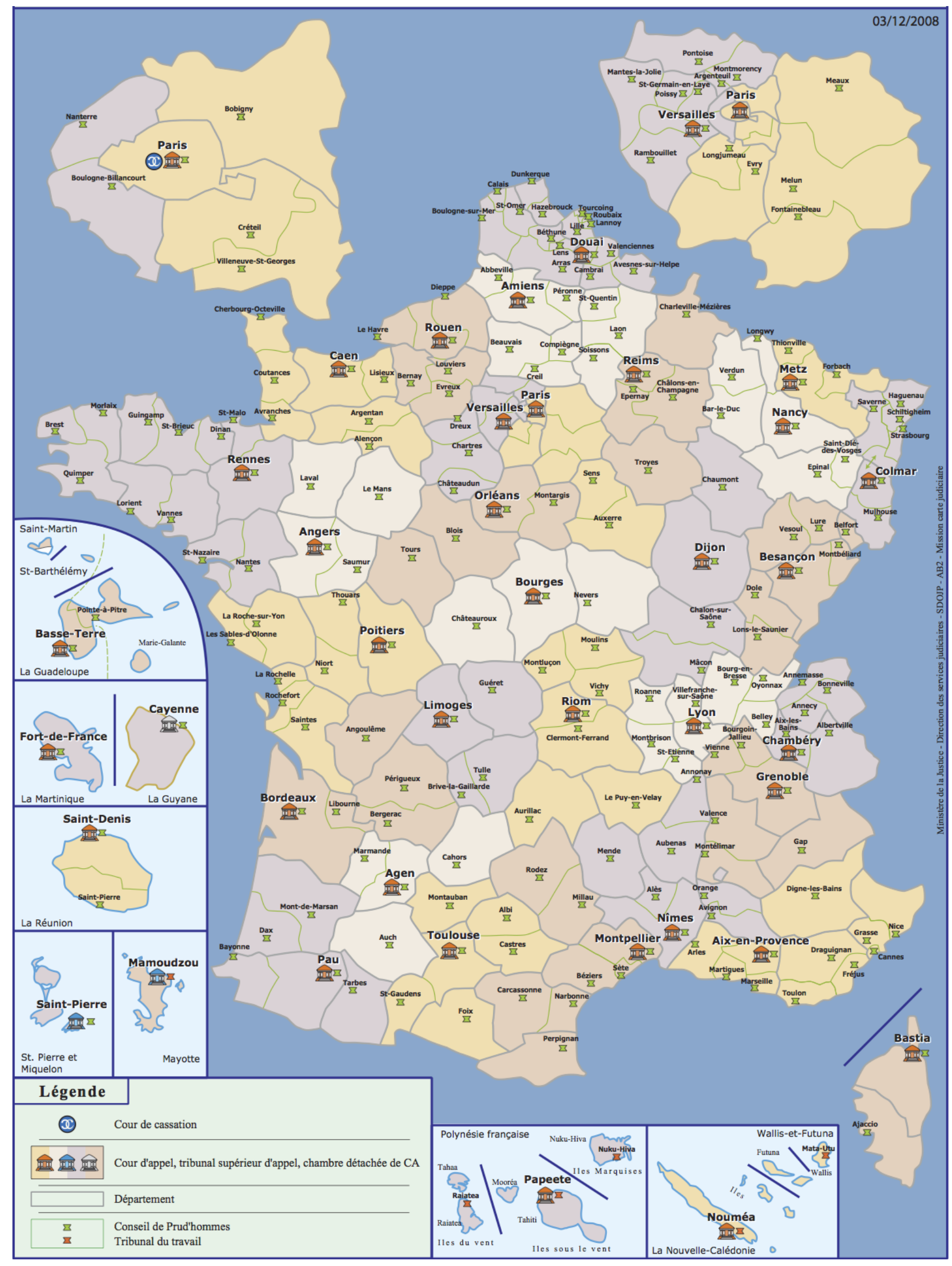


Appendix 2: Tables 
Table 1: Summary statistics in 2007.

\begin{tabular}{|c|c|c|c|c|c|}
\hline Variable & Label & Non-treatable & Removed & Receiving & Untreated \\
\hline unemployed & Number of unemployed workers & $\begin{array}{c}290.044 \\
(966.2)\end{array}$ & $\begin{array}{c}157.265^{* * *} \\
(304.6)\end{array}$ & $\begin{array}{c}262.401 \\
(1054.34)\end{array}$ & $\begin{array}{c}252.625 \\
(863.3)\end{array}$ \\
\hline jobDest & Number of job destructions (registration for unemployment benefits) & $\begin{array}{c}383.916 \\
(1250.4)\end{array}$ & $\begin{array}{c}213.514^{* * *} \\
(412.6)\end{array}$ & $\begin{array}{c}372.36 \\
(1626.2)\end{array}$ & $\begin{array}{l}348.375 \\
(1278.6)\end{array}$ \\
\hline jobCrea & Number of unemployed workers who left unemployment benefits after finding a job & $\begin{array}{c}107.877 \\
(293.1)\end{array}$ & $\begin{array}{c}75.392^{* * *} \\
(122.7)\end{array}$ & $\begin{array}{l}115.219 \\
(415.8)\end{array}$ & $\begin{array}{c}107.769 \\
(304.2)\end{array}$ \\
\hline newEntr & Number of firms created per year & $\begin{array}{l}24.321 \\
(75.49)\end{array}$ & $\begin{array}{c}12.739^{* * *} \\
(22.70)\end{array}$ & $\begin{array}{c}23.581 \\
(103.80)\end{array}$ & $\begin{array}{l}23.775 \\
(81.34)\end{array}$ \\
\hline distance & Distance between the city and its labor court $(\mathrm{km})$ & $\begin{array}{c}28.986 \\
(23.082)\end{array}$ & $\begin{array}{c}17.178^{* * *} \\
(13.215)\end{array}$ & $\begin{array}{c}22.005^{* * *} \\
(21.791)\end{array}$ & $\begin{array}{c}28.618 \\
(54.593)\end{array}$ \\
\hline pop & Population $(\log )$ & $\begin{array}{l}7.728 \\
(.95)\end{array}$ & $\begin{array}{c}7.614^{* * *} \\
(.783)\end{array}$ & $\begin{array}{l}7.768 \\
(.926)\end{array}$ & $\begin{array}{l}7.803 \\
(.95)\end{array}$ \\
\hline popAge & Working age population $(\log )$ & $\begin{array}{l}7.253 \\
(.962)\end{array}$ & $\begin{array}{c}7.159^{* * *} \\
(.779)\end{array}$ & $\begin{array}{l}7.326 \\
(.931)\end{array}$ & $\begin{array}{l}7.355 \\
(.955)\end{array}$ \\
\hline propCS1 & Proportion of individuals in the $1^{\text {st }}$ social category & $\begin{array}{c}.02 \\
(.023)\end{array}$ & $\begin{array}{l}.015 \\
(.019)\end{array}$ & $\begin{array}{c}.012^{* * * *} \\
(.017)\end{array}$ & $\begin{array}{l}.014 \\
(.019)\end{array}$ \\
\hline propCS2 & Proportion of individuals in the $2^{\text {nd }}$ social category & $\begin{array}{l}.039 \\
(.016)\end{array}$ & $\begin{array}{c}.036^{* * *} \\
(.017)\end{array}$ & $\begin{array}{c}.037^{* * * *} \\
(.016)\end{array}$ & $\begin{array}{l}.038 \\
(.017)\end{array}$ \\
\hline propCS3 & Proportion of individuals in the $3^{\text {rd }}$ social category & $\begin{array}{c}.05 \\
(.027)\end{array}$ & $\begin{array}{c}.054^{* * *} \\
(.03)\end{array}$ & $\begin{array}{c}.072^{* * * *} \\
(.043)\end{array}$ & $\begin{array}{l}.068 \\
(.047)\end{array}$ \\
\hline propCS4 & Proportion of individuals in the $4^{\text {th }}$ social category & $\begin{array}{l}.124 \\
(.041)\end{array}$ & $\begin{array}{l}.13^{* * *} \\
(.04)\end{array}$ & $\begin{array}{c}.145^{* * *} \\
(.044)\end{array}$ & $\begin{array}{c}.14 \\
(.043)\end{array}$ \\
\hline propCS5 & Proportion of individuals in the $5^{\text {th }}$ social category & $\begin{array}{l}.169 \\
(.033)\end{array}$ & $\begin{array}{c}.162^{* * *} \\
(.035)\end{array}$ & $\begin{array}{l}.168^{* *} \\
(.035)\end{array}$ & $\begin{array}{l}.166 \\
(.036)\end{array}$ \\
\hline propCS6 & Proportion of individuals in the $6^{\text {th }}$ social category & $\begin{array}{l}.158 \\
(.051)\end{array}$ & $\begin{array}{c}.179^{* * *} \\
(.054)\end{array}$ & $\begin{array}{c}.152^{* * *} \\
(.052)\end{array}$ & $\begin{array}{l}.158 \\
(.056)\end{array}$ \\
\hline propCS7 & Proportion of individuals in the $7^{\text {th }}$ social category & $\begin{array}{c}.298 \\
(.081)\end{array}$ & $\begin{array}{c}.274^{* * *} \\
(.062)\end{array}$ & $\begin{array}{l}.262^{* *} \\
(.069)\end{array}$ & $\begin{array}{l}.266 \\
(.074)\end{array}$ \\
\hline propCS8 & Proportion of individuals in the $8^{\text {th }}$ social category & $\begin{array}{l}.142 \\
(.042)\end{array}$ & $\begin{array}{l}.15 \\
(.042)\end{array}$ & $\begin{array}{l}.153^{* *} \\
(.042)\end{array}$ & $\begin{array}{c}.15 \\
(.041)\end{array}$ \\
\hline newAff ${ }^{\diamond}$ & Number of new claims per year & $\begin{array}{c}991.7 \\
(1108.0)\end{array}$ & $\begin{array}{c}196.2^{* * *} \\
(72.3)\end{array}$ & $\begin{array}{c}1266^{* * *} \\
(1268)\end{array}$ & $\begin{array}{c}926.556 \\
(987.413)\end{array}$ \\
\hline succRate $^{\diamond}$ & Success rate for plaintiffs & $\begin{array}{c}.712 \\
(.092)\end{array}$ & $\begin{array}{l}.74^{* * *} \\
(.128)\end{array}$ & $\begin{array}{c}.722^{* * * *} \\
(.081)\end{array}$ & $\begin{array}{c}.714 \\
(.074)\end{array}$ \\
\hline concRate $^{\diamond}$ & Conciliation rate & $\begin{array}{l}.107 \\
(.052)\end{array}$ & $\begin{array}{c}.127^{* * *} \\
(.054)\end{array}$ & $\begin{array}{c}.118^{* * * *} \\
(.047)\end{array}$ & $\begin{array}{l}.108 \\
(.051)\end{array}$ \\
\hline depRate $^{\diamond}$ & Rate of départage & $\begin{array}{l}16.59 \\
(9.624)\end{array}$ & $\begin{array}{l}8.28^{* * *} \\
(10.353)\end{array}$ & $\begin{array}{l}13.94 \\
(8.769)\end{array}$ & $\begin{array}{c}14.067 \\
(10.205)\end{array}$ \\
\hline durAff ${ }^{\diamond}$ & Average duration of terminated cases in months (log) & $\begin{array}{l}10.443 \\
(2.676)\end{array}$ & $\begin{array}{c}8.355^{* * *} \\
(2.378)\end{array}$ & $\begin{array}{c}11.099^{* *} \\
(3.059)\end{array}$ & $\begin{array}{c}10.94 \\
(3.058)\end{array}$ \\
\hline
\end{tabular}

Means and standard deviations (in parentheses). Variables with $\diamond$ are reported at the labor-court level.

Stars indicate that the sample mean is statistically different from the untreated cities' sample mean at the $10 \%\left({ }^{*}\right), 5 \%\left({ }^{* *}\right)$ and $1 \%\left({ }^{* * *}\right)$ levels. 
Table 2: Estimation of the difference between cities not affected by the reform and cities whose labor court was removed (Differences-in-differences, regression-adjusted, excluding non-treatable cities).

\begin{tabular}{lcccc}
\hline \hline & Job Destruction & Job Creation & Unemployment & New Firms \\
\hline$\phi_{2006}$ & -0.554 & 0.705 & -0.0908 & $-5.252^{* *}$ \\
$\phi_{2008}$ & $(1.031)$ & $(1.345)$ & $(0.533)$ & $(2.445)$ \\
& -0.766 & -1.250 & 0.0920 & 1.433 \\
$\phi_{2009}$ & $(0.782)$ & $(1.152)$ & $(0.435)$ & $(2.684)$ \\
& -0.444 & $-3.456^{* *}$ & 0.126 & -3.481 \\
$\phi_{2010}$ & $(1.462)$ & $(1.504)$ & $(0.829)$ & $(2.403)$ \\
& -2.076 & $-4.020^{* *}$ & 0.140 & -3.357 \\
$\phi_{2011}$ & $(1.443)$ & $(1.862)$ & $(1.223)$ & $(2.268)$ \\
& $-2.661^{*}$ & -2.730 & 1.556 & $-5.236^{* *}$ \\
$\phi_{2012}$ & $(1.425)$ & $(2.061)$ & $(1.561)$ & $(2.049)$ \\
& $-3.536^{* * *}$ & $-3.879^{* *}$ & 1.364 & $-5.771^{* * *}$ \\
City FE & $(1.222)$ & $(1.919)$ & $(1.589)$ & $(1.973)$ \\
Year FE & & & & \\
Covariates & Yes & Yes & Yes & Yes \\
Observations & Yes & Yes & Yes & Yes \\
R-squared & 50,376 & 50,376 & 50,372 & 49,497 \\
\hline \hline
\end{tabular}

Significance level: ${ }^{* * *}$ significant at the $1 \%$ level; ${ }^{* *}$ significant at the $5 \%$ level; $*$ significant at the $10 \%$ level.

Robust standard errors are clustered at the court level. 
Table 3: Estimation of the difference between cities not affected by the reform and cities that experienced a rise in the distance to the labor court (Differences-in-differences, regression-adjusted, excluding non-treatable cities).

\begin{tabular}{lcccc}
\hline \hline & Job Destruction & Job Creation & Unemployment & New Firms \\
\hline$\phi_{I, 2006}$ & -0.579 & 0.596 & 0.108 & $-5.547^{* *}$ \\
$\phi_{I, 2008}$ & $(1.105)$ & $(1.356)$ & $(0.565)$ & $(2.624)$ \\
& -0.789 & -1.723 & -0.00714 & 1.181 \\
$\phi_{I, 2009}$ & $(0.729)$ & $(1.163)$ & $(0.458)$ & $(2.855)$ \\
& -0.411 & $-4.187^{* * *}$ & 0.0137 & -3.976 \\
$\phi_{I, 2010}$ & $(1.487)$ & $(1.538)$ & $(0.897)$ & $(2.429)$ \\
& $-2.506^{*}$ & $-4.781^{* *}$ & 0.107 & $-4.021^{*}$ \\
$\phi_{I, 2011}$ & $(1.427)$ & $(1.957)$ & $(1.270)$ & $(2.298)$ \\
& $-3.118^{* *}$ & -3.319 & 1.576 & $-4.979^{* *}$ \\
$\phi_{I, 2012}$ & $(1.349)$ & $(2.109)$ & $(1.625)$ & $(2.188)$ \\
& $-3.952^{* * *}$ & $-4.651^{* *}$ & 1.475 & $-6.323^{* * *}$ \\
& $(1.200)$ & $(1.993)$ & $(1.646)$ & $(2.051)$ \\
City FE & & & & \\
Year FE & Yes & Yes & Yes & Yes \\
Covariates & Yes & Yes & Yes & Yes \\
Observations & 49,640 & 49,640 & 49,636 & 48,768 \\
R-squared & 0.255 & 0.152 & 0.340 & 0.279 \\
\hline \hline
\end{tabular}

Significance level: *** significant at the $1 \%$ level; ** significant at the $5 \%$ level; * significant at the $10 \%$ level.

Robust standard errors are clustered at the court level. 
Table 4: Estimation of the difference between cities not affected by the reform and cities that experienced a fall in the distance to the labor court (Differences-in-differences, regression-adjusted, excluding non-treatable cities).

\begin{tabular}{lcccc}
\hline \hline & Job Destruction & Job Creation & Unemployment & New Firms \\
\hline$\phi_{D, 2006}$ & -0.271 & 1.603 & $-2.057^{* *}$ & -2.375 \\
& $(1.340)$ & $(2.488)$ & $(0.923)$ & $(6.703)$ \\
$\phi_{D, 2008}$ & -0.324 & 3.504 & 1.351 & 3.859 \\
& $(2.451)$ & $(2.222)$ & $(1.107)$ & $(4.897)$ \\
$\phi_{D, 2009}$ & -1.282 & $4.058^{*}$ & 0.306 & 1.490 \\
& $(2.542)$ & $(2.199)$ & $(1.637)$ & $(4.476)$ \\
$\phi_{D, 2010}$ & 2.015 & 3.773 & -0.343 & 3.033 \\
& $(3.320)$ & $(3.825)$ & $(2.273)$ & $(5.659)$ \\
$\phi_{D, 2011}$ & 1.746 & 3.238 & 0.592 & $-8.051^{*}$ \\
& $(4.530)$ & $(2.973)$ & $(3.116)$ & $(4.697)$ \\
$\phi_{D, 2012}$ & 0.591 & 3.922 & -0.463 & -0.630 \\
& $(3.303)$ & $(2.829)$ & $(3.000)$ & $(3.727)$ \\
City FE & & & & \\
Year FE & Yes & Yes & Yes & Yes \\
Covariates & Yes & Yes & Yes & Yes \\
Observations & 42,891 & 42,891 & 42,901 & 42,228 \\
R-squared & 0.267 & 0.138 & 0.348 & 0.278 \\
\hline \hline
\end{tabular}

Significance level: *** significant at the $1 \%$ level; ** significant at the $5 \%$ level; * significant at the $10 \%$ level.

Robust standard errors are clustered at the court level. 
Table 5: Diagnosis of the matching process: Average standardized bias and number of biased variables at $5 \%$ (excluding non-treatable cities).

\begin{tabular}{ccccc}
\hline \hline & \multicolumn{2}{c}{ Increased Distance } & \multicolumn{2}{c}{ Reduced Distance } \\
\hline Algorithm & Average Bias & №. Biased Var. & Average Bias & №. Biased Var. \\
\hline Before Matching & 4.44 & 2 & 7.25 & 2 \\
EK & 2.82 & 0 & 7.28 & 2 \\
GK & 3.63 & 0 & 7.27 & 2 \\
N3 & 1.28 & 0 & 4.92 & 2 \\
CBPS & 0.06 & 0 & 0.03 & 0 \\
\hline \hline
\end{tabular}

Table 6: Estimation of the difference between cities not affected by the reform and cities that experienced a rise in the distance to the labor court (Conditional differences-in-differences, regressionadjusted, excluding non-treatable cities).

\begin{tabular}{lcccc}
\hline \hline & Job Destruction & Job Creation & Unemployment & New Firms \\
\hline$\phi_{I, 2006}$ & -0.0423 & -0.206 & -0.330 & 0.354 \\
$\phi_{I, 2008}$ & $(1.015)$ & $(1.326)$ & $(0.526)$ & $(2.525)$ \\
& -0.349 & $-2.461^{* *}$ & -0.172 & 4.300 \\
$\phi_{I, 2009}$ & $(0.727)$ & $(1.149)$ & $(0.440)$ & $(2.809)$ \\
& 0.145 & $-5.085^{* * *}$ & -0.0715 & -3.089 \\
$\phi_{I, 2010}$ & $(1.474)$ & $(1.626)$ & $(1.057)$ & $(2.538)$ \\
& -2.102 & $-5.848^{* * *}$ & 0.192 & -2.825 \\
$\phi_{I, 2011}$ & $(1.392)$ & $(2.033)$ & $(1.426)$ & $(2.327)$ \\
& $-2.845^{* *}$ & $-4.582^{* *}$ & 1.765 & $-4.116^{*}$ \\
$\phi_{I, 2012}$ & $(1.316)$ & $(2.120)$ & $(1.786)$ & $(2.255)$ \\
& $-3.834^{* * *}$ & $-5.792^{* * *}$ & 1.299 & $-5.420^{* *}$ \\
City FE & $(1.177)$ & $(2.058)$ & $(1.829)$ & $(2.264)$ \\
Year FE & & & & \\
Covariates & Yes & Yes & Yes & Yes \\
Observations & Yes & Yes & Yes & Yes \\
R-squared & 48,752 & 48,752 & 48,755 & 48,754 \\
\hline \hline
\end{tabular}

Significance level: $* * *$ significant at the $1 \%$ level; $* *$ significant at the $5 \%$ level; $*$ significant at the $10 \%$ level.

Robust standard errors are clustered at the court level. 
Table 7: Estimation of the difference between cities not affected by the reform and cities that experienced a fall in the distance to the labor court (Conditional differences-in-differences, regressionadjusted, excluding non-treatable cities).

\begin{tabular}{lcccc}
\hline \hline & Job Destruction & Job Creation & Unemployment & New Firms \\
\hline$\phi_{D, 2006}$ & 0.641 & 0.00567 & -0.151 & -3.459 \\
$\phi_{D, 2008}$ & $(1.290)$ & $(2.343)$ & $(0.900)$ & $(6.968)$ \\
& -1.097 & 2.990 & 1.296 & 4.696 \\
$\phi_{D, 2009}$ & $(2.305)$ & $(2.206)$ & $(1.170)$ & $(4.812)$ \\
& -0.314 & 1.644 & $2.554^{* *}$ & 0.0869 \\
$\phi_{D, 2010}$ & $(2.293)$ & $(2.373)$ & $(1.234)$ & $(5.558)$ \\
& 2.958 & 1.755 & 1.978 & 2.969 \\
$\phi_{D, 2011}$ & $(3.072)$ & $(3.366)$ & $(1.963)$ & $(6.231)$ \\
& 2.661 & 1.296 & 2.881 & -8.300 \\
$\phi_{D, 2012}$ & $(4.172)$ & $(3.150)$ & $(2.535)$ & $(5.249)$ \\
& 0.622 & 2.636 & 2.833 & 0.421 \\
& $(3.136)$ & $(2.715)$ & $(2.615)$ & $(4.030)$ \\
City FE & & & & \\
Year FE & Yes & Yes & Yes & Yes \\
Covariates & Yes & Yes & Yes & Yes \\
Observations & 42,226 & 42,226 & 42,229 & 42,228 \\
R-squared & 0.272 & 0.130 & 0.381 & 0.282 \\
\hline \hline
\end{tabular}

Significance level: *** significant at the $1 \%$ level; ** significant at the $5 \%$ level; * significant at the $10 \%$ level.

Robust standard errors are clustered at the court level. 
Table 8: Linear estimation of the effect of a change of distance. (No matching-correction, excluding non-treatable cities.)

\begin{tabular}{lcccc}
\hline \hline & Job Destruction & Job Creation & Unemployment & New Firms \\
\hline$\phi_{2006}$ & -0.0129 & 0.0426 & 0.0183 & $-0.145^{* *}$ \\
& $(0.0361)$ & $(0.0382)$ & $(0.0195)$ & $(0.0708)$ \\
$\phi_{2008}$ & -0.0283 & $-0.0666^{* *}$ & -0.00349 & -0.0245 \\
& $(0.0203)$ & $(0.0331)$ & $(0.0128)$ & $(0.0843)$ \\
$\phi_{2009}$ & -0.0131 & $-0.141^{* * *}$ & -0.00997 & $-0.123^{*}$ \\
& $(0.0436)$ & $(0.0420)$ & $(0.0232)$ & $(0.0667)$ \\
$\phi_{2010}$ & $-0.0973^{* * *}$ & $-0.140^{* * *}$ & -0.0129 & $-0.138^{*}$ \\
& $(0.0291)$ & $(0.0532)$ & $(0.0302)$ & $(0.0760)$ \\
$\phi_{2011}$ & $-0.0976^{* * *}$ & $-0.103^{*}$ & 0.0292 & $-0.123^{* *}$ \\
& $(0.0335)$ & $(0.0568)$ & $(0.0495)$ & $(0.0607)$ \\
$\phi_{2012}$ & $-0.0950^{* * *}$ & $-0.123^{* *}$ & 0.0473 & $-0.219^{* * *}$ \\
& $(0.0333)$ & $(0.0520)$ & $(0.0455)$ & $(0.0462)$ \\
City FE & Yes & Yes & Yes & Yes \\
Year FE & Yes & Yes & Yes & Yes \\
Covariates & Yes & Yes & Yes & Yes \\
Observations & 50,371 & 50,371 & 50,367 & 49,492 \\
R-squared & 0.255 & 0.151 & 0.341 & 0.279 \\
\hline \hline
\end{tabular}

Significance level: $* * *$ significant at the $1 \%$ level; ${ }^{* *}$ significant at the $5 \%$ level; * significant at the $10 \%$ level.

Robust standard errors are clustered at the court level. 
Table 9: Linear estimation of the effect of a change of distance. (With matching-correction, excluding non-treatable cities.)

\begin{tabular}{lcccc}
\hline \hline & Job Destruction & Job Creation & Unemployment & New Firms \\
\hline$\phi_{2006}$ & -0.00765 & 0.00242 & 0.0151 & -0.0287 \\
& $(0.0323)$ & $(0.0330)$ & $(0.0185)$ & $(0.0663)$ \\
$\phi_{2008}$ & -0.0139 & $-0.111^{* * *}$ & -0.0129 & 0.00129 \\
& $(0.0204)$ & $(0.0272)$ & $(0.00988)$ & $(0.0844)$ \\
$\phi_{2009}$ & -0.00485 & $-0.178^{* * *}$ & -0.0206 & -0.0939 \\
& $(0.0444)$ & $(0.0358)$ & $(0.0233)$ & $(0.0654)$ \\
$\phi_{2010}$ & $-0.0937^{* * *}$ & $-0.169^{* * *}$ & -0.0202 & -0.111 \\
& $(0.0253)$ & $(0.0506)$ & $(0.0271)$ & $(0.0772)$ \\
$\phi_{2011}$ & $-0.0925^{* * *}$ & $-0.147^{* * *}$ & 0.0192 & -0.0751 \\
& $(0.0319)$ & $(0.0494)$ & $(0.0498)$ & $(0.0568)$ \\
$\phi_{2012}$ & $-0.0807^{* *}$ & $-0.151^{* * *}$ & 0.0429 & $-0.188^{* * *}$ \\
& $(0.0316)$ & $(0.0479)$ & $(0.0468)$ & $(0.0425)$ \\
City FE & & & & \\
Year FE & Yes & Yes & Yes & Yes \\
Covariates & Yes & Yes & Yes & Yes \\
Observations & 49,476 & 49,476 & 49,479 & 49,478 \\
R-squared & 0.236 & 0.185 & 0.333 & 0.289 \\
\hline \hline
\end{tabular}

Significance level: $* * *$ significant at the $1 \%$ level; ${ }^{* *}$ significant at the $5 \%$ level; * significant at the $10 \%$ level.

Robust standard errors are clustered at the court level. 


\section{Appendix 3: Decision to remove courts}

The decision to remove courts in 2008 mainly resulted from the government's will to reduce public expenditures. In French history, reductions of the number of courts, and more broadly amendments of the judicial map, turn to be rare events. Indeed, prior to 2008, the last significant reform dated back to 1958 .

In 2008, the government had therefore a unique opportunity to substantially amend the judicial map. During the preliminary discussions, the government declared that the courts to be removed would be chosen in the light of their level of activity. We propose here a few elements to see whether (i) the government effectively based its choice on the court's activity level, and (ii) whether some dimensions of the labor market under scrutiny affected its decision.

To do so, we consider data of 2007 at the court level. The dependent variable is a dummy variable equal to 1 if the court was removed and to 0 otherwise. The independent variables include variables about the court (the number of new cases, the average delay to obtain a decision, the average winning rate for the plaintiffs, the average conciliation rate, and the average so-called départage rate which accounts for a procedure specific to French labor courts), and average values of the job market outcomes considered in our study (job destructions, job creations, new enterprises, unemployed workers). ${ }^{30}$

Table 10 shows the results of probit estimation of the probability of a court to be removed. It excludes labor courts that were unique in their département, since the government refused to remove such courts. Sample A includes removed courts and courts that were not affected by the reform. Sample B also includes courts that took on the competency of removed courts. As one can see, the court's activity, i.e. the number of new cases, has been the main criterion to determine the removal of courts. We observe indeed that this only criterion explains almost $47 \%$ of the removal decision. Furthermore, it appears that the government did not consider issues related to the labor market conditions when deciding on the reform: none of the coefficients associated to these variables is significant in the regression.

\footnotetext{
${ }^{30}$ Note that the averages of the outcome variables are weighted by the population in working age.
} 
Table 10: Probit regressions of the probability of being removed. (Z-values in parentheses.)

\begin{tabular}{lcccc}
\hline \hline & $(1)$ & $(2)$ & $(3)$ & $(4)$ \\
& Sample A & Sample B & Sample A & Sample B \\
\hline New Cases & $-0.0097^{* * *}$ & $-0.0093^{* * *}$ & $-0091^{* * *}$ & $-0.0092^{* * *}$ \\
Winning Rate & $(-5.16)$ & $(-5.34)$ & $(-5.94)$ & $(-6.13)$ \\
& 1.100 & 1.527 & & \\
Conciliation Rate & -0.89 & -1.33 & & \\
& 1.428 & 1.107 & & \\
Départage Rate & -0.57 & -0.47 & & \\
Job destructions & 0.0058 & 0.0113 & & \\
& -0.43 & -0.86 & & \\
Job creations & -0.0010 & -0.0017 & & \\
New Enterprises & $(-0.57)$ & $(-1.02)$ & & \\
& 0.0011 & 0.0020 & & \\
Unemployed Workers & -0.3 & -0.55 & & \\
& 0.0031 & 0.0029 & & 0.4609 \\
Average Duration & -0.25 & -0.26 & & \\
& 0.0007 & 0.0012 & & \\
Observations & -0.55 & -1.01 & & \\
Pseudo R & $-0.1326^{* *}$ & $-0.1337^{* *}$ & & \\
\hline \hline
\end{tabular}




\title{
ONLINE APPENDIX
}

\author{
Labor Market \& Access to Justice \\ Romain Espinosa, Claudine Desrieux and Marc Ferracci
}

\section{Differences-in-Differences}

Table A1: Estimation of the difference between cities not affected by the reform and cities whose labor court was removed (Differences-in-differences, regression-adjusted, excluding non-treatable cities).

\begin{tabular}{lcccc}
\hline \hline & Job Destruction & Job Creation & Unemployment & New Firms \\
\hline$\phi_{2006}$ & -0.691 & 0.626 & -0.109 & $-5.707^{* *}$ \\
& $(1.040)$ & $(1.315)$ & $(0.529)$ & $(2.403)$ \\
$\phi_{2008}$ & -0.610 & -1.114 & 0.149 & 0.626 \\
& $(0.782)$ & $(1.129)$ & $(0.422)$ & $(2.682)$ \\
$\phi_{2009}$ & 0.107 & $-3.465^{* *}$ & 0.184 & -3.210 \\
& $(1.453)$ & $(1.494)$ & $(0.829)$ & $(2.389)$ \\
$\phi_{2010}$ & -1.786 & $-3.698^{* *}$ & 0.206 & -3.054 \\
& $(1.437)$ & $(1.836)$ & $(1.216)$ & $(2.243)$ \\
$\phi_{2011}$ & $-2.485^{*}$ & -2.468 & 1.677 & $-4.493^{* *}$ \\
& $(1.411)$ & $(2.035)$ & $(1.539)$ & $(2.033)$ \\
$\phi_{2012}$ & $-3.463^{* * *}$ & $-3.668^{*}$ & 1.530 & $-5.394^{* * *}$ \\
& $(1.210)$ & $(1.880)$ & $(1.562)$ & $(1.972)$ \\
City FE & & & & \\
Year FE & Yes & Yes & Yes & Yes \\
Covariates & Yes & Yes & Yes & Yes \\
Observations & 57,124 & 57,121 & 57,120 & 56,147 \\
R-squared & 0.243 & 0.155 & 0.340 & 0.279 \\
\hline \hline
\end{tabular}

Significance level: ${ }^{* * *}$ significant at the $1 \%$ level; ${ }^{* *}$ significant at the $5 \%$ level; * significant at the $10 \%$ level.

Robust standard errors are clustered at the court level. 
Table A2: Estimation of the difference between cities not affected by the reform and cities that experienced a rise in the distance to the labor court (Differences-in-differences, regression-adjusted, including non-treatable cities).

\begin{tabular}{lcccc}
\hline \hline & Job Destruction & Job Creation & Unemployment & New Firms \\
\hline$\phi_{I, 2006}$ & -0.710 & 0.521 & 0.0904 & $-5.991^{* *}$ \\
$\phi_{I, 2008}$ & $(0.525)$ & $(0.695)$ & $(0.872)$ & $(0.0216)$ \\
& -0.632 & -1.580 & 0.0515 & 0.375 \\
$\phi_{I, 2009}$ & $(0.387)$ & $(0.168)$ & $(0.908)$ & $(0.895)$ \\
& 0.142 & $-4.201^{* * *}$ & 0.0706 & -3.706 \\
$\phi_{I, 2010}$ & $(0.923)$ & $(0.00642)$ & $(0.937)$ & $(0.127)$ \\
& -2.215 & $-4.461^{* *}$ & 0.172 & -3.718 \\
$\phi_{I, 2011}$ & $(0.120)$ & $(0.0220)$ & $(0.892)$ & $(0.103)$ \\
& $-2.937^{* *}$ & -3.056 & 1.697 & $-4.227^{*}$ \\
$\phi_{I, 2012}$ & $(0.0281)$ & $(0.144)$ & $(0.291)$ & $(0.0532)$ \\
& $-3.874^{* * *}$ & $-4.442^{* *}$ & 1.640 & $-5.934^{* * *}$ \\
& $(0.00122)$ & $(0.0239)$ & $(0.312)$ & $(0.00419)$ \\
City FE & & & & \\
Year FE & Yes & Yes & Yes & Yes \\
Covariates & Yes & Yes & Yes & Yes \\
Observations & 56,388 & 56,385 & 56,384 & 55,418 \\
R-squared & 0.243 & 0.157 & 0.340 & 0.279 \\
\hline \hline
\end{tabular}

Significance level: *** significant at the $1 \%$ level; ${ }^{* *}$ significant at the $5 \%$ level; * significant at the $10 \%$ level.

Robust standard errors are clustered at the court level. 
Table A3: Estimation of the difference between cities not affected by the reform and cities that experienced a fall in the distance to the labor court (Differences-in-differences, regression-adjusted, including non-treatable cities).

\begin{tabular}{lcccc}
\hline \hline & Job Destruction & Job Creation & Unemployment & New Firms \\
\hline$\phi_{D, 2006}$ & -0.482 & 1.494 & $-2.078^{* *}$ & -2.944 \\
$\phi_{D, 2008}$ & $(0.726)$ & $(0.544)$ & $(0.0250)$ & $(0.660)$ \\
& -0.158 & 3.600 & 1.373 & 3.101 \\
$\phi_{D, 2009}$ & $(0.949)$ & $(0.104)$ & $(0.213)$ & $(0.534)$ \\
& -0.910 & $3.942^{*}$ & 0.405 & 1.735 \\
$\phi_{D, 2010}$ & $(0.723)$ & $(0.0763)$ & $(0.806)$ & $(0.697)$ \\
& 2.116 & 3.932 & -0.241 & 3.359 \\
$\phi_{D, 2011}$ & $(0.536)$ & $(0.295)$ & $(0.916)$ & $(0.557)$ \\
& 1.693 & 3.312 & 0.729 & -7.386 \\
$\phi_{D, 2012}$ & $(0.717)$ & $(0.266)$ & $(0.815)$ & $(0.118)$ \\
& 0.470 & 3.952 & -0.257 & -0.378 \\
& $(0.891)$ & $(0.159)$ & $(0.932)$ & $(0.921)$ \\
City FE & & & & \\
Year FE & Yes & Yes & Yes & Yes \\
Covariates & Yes & Yes & Yes & Yes \\
Observations & 49,639 & 49,636 & 49,649 & 48,878 \\
R-squared & 0.252 & 0.145 & 0.347 & 0.278 \\
\hline \hline
\end{tabular}

Significance level: *** significant at the $1 \%$ level; ${ }^{* *}$ significant at the $5 \%$ level; * significant at the $10 \%$ level.

Robust standard errors are clustered at the court level. 
Table A4: Estimation of the difference between cities not affected by the reform and cities that experienced a rise in the distance to the labor court (Differences-in-differences, regression-adjusted, excluding non-treatable cities, Multilevel mixed effects).

\begin{tabular}{lcccc}
\hline \hline & Job Destruction & Job Creation & Unemployment & New Firms \\
\hline$\phi_{I, 2006}$ & -0.443 & 1.788 & -0.218 & $-5.569^{* *}$ \\
$\phi_{I, 2008}$ & $(0.979)$ & $(1.385)$ & $(0.884)$ & $(2.260)$ \\
& -0.522 & -0.950 & -1.185 & 1.428 \\
$\phi_{I, 2009}$ & $(0.992)$ & $(1.402)$ & $(0.896)$ & $(2.292)$ \\
& -1.065 & $-4.647^{* * *}$ & -0.644 & -2.079 \\
$\phi_{I, 2010}$ & $(0.965)$ & $(1.364)$ & $(0.870)$ & $(2.220)$ \\
& $-2.778^{* * *}$ & $-4.839^{* * *}$ & -0.821 & -2.695 \\
$\phi_{I, 2011}$ & $(0.964)$ & $(1.364)$ & $(0.870)$ & $(2.219)$ \\
& $-2.916^{* * *}$ & $-4.535^{* * *}$ & 0.552 & -3.648 \\
$\phi_{I, 2012}$ & $(0.964)$ & $(1.363)$ & $(0.869)$ & $(2.219)$ \\
& $-4.338^{* * *}$ & $-5.749^{* * *}$ & 0.248 & $-4.793^{* *}$ \\
& $(0.965)$ & $(1.364)$ & $(0.870)$ & $(2.221)$ \\
City RE & & & & \\
Year FE & Yes & Yes & Yes & Yes \\
Court $\times$ Year RE & Yes & Yes & Yes & Yes \\
Covariates & Yes & Yes & Yes & Yes \\
Observations & Yes & Yes & Yes & Yes \\
\hline \hline
\end{tabular}

Significance level: ${ }^{* * *}$ significant at the $1 \%$ level; ${ }^{* *}$ significant at the $5 \%$ level; ${ }^{*}$ significant at the $10 \%$ level. 
Table A5: Estimation of the difference between cities not affected by the reform and cities that experienced a fall in the distance to the labor court (Differences-in-differences, regression-adjusted, excluding non-treatable cities, Multilevel mixed effects).

\begin{tabular}{lcccc}
\hline \hline & Job Destruction & Job Creation & Unemployment & New Firms \\
\hline$\phi_{D, 2006}$ & -0.375 & 2.255 & -3.312 & -1.943 \\
& $(2.347)$ & $(3.297)$ & $(2.251)$ & $(6.220)$ \\
$\phi_{D, 2008}$ & -1.281 & 3.565 & 0.0155 & 4.167 \\
& $(2.377)$ & $(3.341)$ & $(2.277)$ & $(6.287)$ \\
$\phi_{D, 2009}$ & -0.513 & 2.648 & -0.665 & 2.159 \\
& $(2.272)$ & $(3.190)$ & $(2.180)$ & $(6.033)$ \\
$\phi_{D, 2010}$ & 1.473 & $5.370 *$ & -1.650 & 4.158 \\
& $(2.270)$ & $(3.188)$ & $(2.179)$ & $(6.030)$ \\
$\phi_{D, 2011}$ & 0.249 & 2.045 & -0.967 & -7.222 \\
& $(2.271)$ & $(3.189)$ & $(2.180)$ & $(6.033)$ \\
$\phi_{D, 2012}$ & -0.823 & 4.029 & -1.853 & 0.562 \\
& $(2.271)$ & $(3.189)$ & $(2.180)$ & $(6.033)$ \\
City RE & & & & \\
Year FE & Yes & Yes & Yes & Yes \\
Court $\times$ Year RE & Yes & Yes & Yes & Yes \\
Covariates & Yes & Yes & Yes & Yes \\
Observations & 42,891 & Yes & Yes & Yes \\
\hline \hline
\end{tabular}

Significance level: ${ }^{* * *}$ significant at the $1 \%$ level; ${ }^{* *}$ significant at the $5 \%$ level; ${ }^{*}$ significant at the $10 \%$ level. 


\section{Conditional Differences-in-Differences}

Table A6: Diagnosis of the matching process: Average standardized bias and number of biased variables at 5\% (including non-treatable cities).

\begin{tabular}{ccccc}
\hline \hline & \multicolumn{2}{c}{ Increased Distance } & \multicolumn{2}{c}{ Reduced Distance } \\
\hline Algorithm & Average Bias & №. Biased Var. & Average Bias & №. Biased Var. \\
\hline Before Matching & 4.64 & 2 & 7.27 & 2 \\
EK & 2.89 & 0 & 7.28 & 2 \\
GK & 3.81 & 2 & 7.28 & 2 \\
N3 & 0.74 & 0 & 5.33 & 2 \\
CBPS & 0.05 & 0 & 0.03 & 0 \\
\hline \hline
\end{tabular}

Table A7: Estimation of the difference between cities not affected by the reform and cities that experienced a rise in the distance to the labor court (Conditional differences-in-differences, regressionadjusted, including non-treatable cities).

\begin{tabular}{lcccc}
\hline \hline & Job Destruction & Job Creation & Unemployment & New Firms \\
\hline$\phi_{I, 2006}$ & -0.0567 & -0.218 & -0.326 & 0.382 \\
$\phi_{I, 2008}$ & $(1.018)$ & $(1.301)$ & $(0.521)$ & $(2.495)$ \\
& -0.131 & $-2.357^{* *}$ & -0.129 & 3.771 \\
$\phi_{I, 2009}$ & $(0.722)$ & $(1.124)$ & $(0.428)$ & $(2.797)$ \\
& 0.889 & $-4.932^{* * *}$ & -0.0434 & -2.812 \\
$\phi_{I, 2010}$ & $(1.465)$ & $(1.632)$ & $(1.071)$ & $(2.530)$ \\
& -1.615 & $-5.333^{* * *}$ & 0.239 & -2.493 \\
$\phi_{I, 2011}$ & $(1.381)$ & $(2.016)$ & $(1.431)$ & $(2.302)$ \\
& $-2.490^{*}$ & $-4.132^{*}$ & 1.833 & -3.329 \\
$\phi_{I, 2012}$ & $(1.301)$ & $(2.109)$ & $(1.778)$ & $(2.243)$ \\
& $-3.571^{* * *}$ & $-5.389^{* * *}$ & 1.426 & $-5.031^{* *}$ \\
City FE & $(1.172)$ & $(2.039)$ & $(1.814)$ & $(2.260)$ \\
Year FE & & & & \\
Covariates & Yes & Yes & Yes & Yes \\
Observations & Yes & Yes & Yes & Yes \\
R-squared & 55,395 & 55,394 & 55,398 & Yes \\
\hline \hline
\end{tabular}

Significance level: *** significant at the $1 \%$ level; ** significant at the $5 \%$ level; * significant at the $10 \%$ level.

Robust standard errors are clustered at the court level. 
Table A8: Estimation of the difference between cities not affected by the reform and cities that experienced a fall in the distance to the labor court (Conditional differences-in-differences, regressionadjusted, including non-treatable cities).

\begin{tabular}{lcccc}
\hline \hline & Job Destruction & Job Creation & Unemployment & New Firms \\
\hline$\phi_{D, 2006}$ & 0.608 & -0.00404 & -0.154 & -3.451 \\
& $(1.294)$ & $(2.318)$ & $(0.890)$ & $(6.915)$ \\
$\phi_{D, 2008}$ & -0.894 & 3.100 & 1.294 & 4.066 \\
& $(2.298)$ & $(2.186)$ & $(1.160)$ & $(4.833)$ \\
$\phi_{D, 2009}$ & 0.376 & 1.658 & $2.727^{* *}$ & 0.444 \\
& $(2.300)$ & $(2.411)$ & $(1.224)$ & $(5.610)$ \\
$\phi_{D, 2010}$ & 3.346 & 2.186 & 2.121 & 3.357 \\
& $(3.122)$ & $(3.278)$ & $(1.947)$ & $(6.283)$ \\
$\phi_{D, 2011}$ & 2.888 & 1.622 & 3.070 & -7.466 \\
& $(4.237)$ & $(3.175)$ & $(2.500)$ & $(5.316)$ \\
$\phi_{D, 2012}$ & 0.695 & 2.950 & 3.071 & 0.885 \\
& $(3.194)$ & $(2.703)$ & $(2.576)$ & $(4.083)$ \\
City FE & & & & \\
Year FE & Yes & Yes & Yes & Yes \\
Covariates & Yes & Yes & Yes & Yes \\
Observations & 48,869 & 48,868 & 48,872 & 48,871 \\
R-squared & 0.266 & 0.133 & 0.380 & 0.282 \\
\hline \hline
\end{tabular}

Significance level: *** significant at the $1 \%$ level; ** significant at the $5 \%$ level; * significant at the $10 \%$ level.

Robust standard errors are clustered at the court level. 
Table A9: Estimation of the difference between cities not affected by the reform and cities that experienced a rise in the distance to the labor court (Conditional differences-in-differences, regressionadjusted, excluding non-treatable cities, including delay in cases at the labor court).

\begin{tabular}{lcccc}
\hline \hline & Job Destruction & Job Creation & Unemployment & New Firms \\
\hline$\phi_{I, 2006}$ & -0.158 & -0.226 & -0.311 & 0.501 \\
$\phi_{I, 2008}$ & $(1.002)$ & $(1.312)$ & $(0.520)$ & $(2.508)$ \\
& $\cdot$ & $\cdot$ & $\cdot$ & $\cdot$ \\
$\phi_{I, 2009}$ & & & & \\
& 0.305 & $-5.340^{* * *}$ & 0.263 & -2.362 \\
$\phi_{I, 2010}$ & $(1.501)$ & $(1.654)$ & $(1.169)$ & $(2.503)$ \\
& -1.943 & $-6.033^{* * *}$ & 0.492 & -2.043 \\
$\phi_{I, 2011}$ & $(1.365)$ & $(2.030)$ & $(1.534)$ & $(2.386)$ \\
& $-2.706^{* *}$ & $-4.770^{* *}$ & 2.057 & -3.400 \\
$\phi_{I, 2012}$ & $(1.315)$ & $(2.211)$ & $(1.874)$ & $(2.293)$ \\
& $-3.672^{* * *}$ & $-5.895^{* * *}$ & 1.555 & $-4.783^{* *}$ \\
Delay in cases & $(1.175)$ & $(2.048)$ & $(1.898)$ & $(2.212)$ \\
City FE & & & & \\
Year FE & Yes & Yes & Yes & Yes \\
Covariates & Yes & Yes & Yes & Yes \\
Observations & Yes & Yes & Yes & Yes \\
R-squared & 41,837 & 41,837 & 41,840 & 41,839 \\
\hline \hline
\end{tabular}

Significance level: ${ }^{* * *}$ significant at the $1 \%$ level; ${ }^{* *}$ significant at the $5 \%$ level; ${ }^{*}$ significant at the $10 \%$ level.

Robust standard errors are clustered at the court level. 
Table A10: Estimation of the difference between cities not affected by the reform and cities that experienced a fall in the distance to their labor court (Conditional differences-in-differences, regressionadjusted, excluding non-treatable cities, including delay in cases at the labor court).

\begin{tabular}{lcccc}
\hline \hline & Job Destruction & Job Creation & Unemployment & New Firms \\
\hline$\phi_{D, 2006}$ & 0.645 & 0.0157 & -0.0756 & -3.203 \\
$\phi_{D, 2008}$ & $(1.305)$ & $(2.415)$ & $(0.917)$ & $(6.917)$ \\
& $\cdot$ & $\cdot$ & $\cdot$ & $\cdot$ \\
$\phi_{D, 2009}$ & & & & \\
& -0.183 & 0.642 & $2.945^{* *}$ & 0.0520 \\
$\phi_{D, 2010}$ & $(2.379)$ & $(2.809)$ & $(1.363)$ & $(6.062)$ \\
& 3.270 & 0.835 & 2.293 & 3.124 \\
$\phi_{D, 2011}$ & $(3.094)$ & $(3.275)$ & $(1.935)$ & $(6.209)$ \\
& 3.121 & 0.395 & 3.231 & -7.810 \\
$\phi_{D, 2012}$ & $(4.242)$ & $(3.429)$ & $(2.582)$ & $(4.856)$ \\
& 1.058 & 1.608 & 3.087 & 0.632 \\
Delay in cases & $(3.076)$ & $(3.044)$ & $(2.595)$ & $(3.976)$ \\
City FE & & & & \\
Year FE & Yes & Yes & Yes & Yes \\
Covariates & Yes & Yes & Yes & Yes \\
Observations & Yes & Yes & Yes & Yes \\
R-squared & 36,197 & 36,197 & 36,200 & 36,199 \\
\hline \hline
\end{tabular}

Significance level: ${ }^{* * *}$ significant at the $1 \%$ level; ${ }^{* *}$ significant at the $5 \%$ level; ${ }^{*}$ significant at the $10 \%$ level.

Robust standard errors are clustered at the court level. 
Table A11: Estimation of the difference between cities not affected by the reform and cities that experienced a rise in the distance to the labor court (Conditional differences-in-differences, regressionadjusted, excluding non-treatable cities, 3-nearest neighbor matching algorithm).

\begin{tabular}{lcccc}
\hline \hline & Job Destruction & Job Creation & Unemployment & New Firms \\
\hline$\phi_{I, 2006}$ & -0.340 & -0.665 & -0.159 & 0.989 \\
$\phi_{I, 2008}$ & $(1.064)$ & $(1.448)$ & $(0.542)$ & $(2.796)$ \\
& -0.864 & $-2.254^{*}$ & 0.0661 & 4.751 \\
$\phi_{I, 2009}$ & $(0.794)$ & $(1.232)$ & $(0.461)$ & $(3.230)$ \\
& -0.246 & $-4.952^{* * *}$ & 0.279 & -2.290 \\
$\phi_{I, 2010}$ & $(1.526)$ & $(1.758)$ & $(1.096)$ & $(2.646)$ \\
& $-2.518^{*}$ & $-5.966^{* * *}$ & 0.239 & -2.053 \\
$\phi_{I, 2011}$ & $(1.437)$ & $(2.085)$ & $(1.460)$ & $(2.380)$ \\
& $-3.662^{* * *}$ & $-5.147^{* *}$ & 1.677 & $-4.047^{*}$ \\
$\phi_{I, 2012}$ & $(1.383)$ & $(2.218)$ & $(1.829)$ & $(2.432)$ \\
& $-4.225^{* * *}$ & $-6.560^{* * *}$ & 1.025 & $-5.363^{* *}$ \\
& $(1.256)$ & $(2.174)$ & $(1.901)$ & $(2.504)$ \\
City FE & & & & \\
Year FE & Yes & Yes & Yes & Yes \\
Covariates & Yes & Yes & Yes & Yes \\
Observations & 24,142 & 24,142 & 24,142 & 24,142 \\
R-squared & 0.237 & 0.192 & 0.340 & 0.294 \\
\hline \hline
\end{tabular}

Significance level: ${ }^{* * *}$ significant at the $1 \%$ level; ${ }^{* *}$ significant at the $5 \%$ level; * significant at the $10 \%$ level.

Robust standard errors are clustered at the court level. 
Table A12: Estimation of the difference between cities not affected by the reform and cities that experienced a fall in the distance to the labor court (Conditional differences-in-differences, regressionadjusted, excluding non-treatable cities, 3-nearest neighbor matching algorithm).

\begin{tabular}{lcccc}
\hline \hline & Job Destruction & Job Creation & Unemployment & New Firms \\
\hline$\phi_{D, 2006}$ & 0.318 & -2.345 & -0.472 & -7.530 \\
& $(1.766)$ & $(3.052)$ & $(0.976)$ & $(8.456)$ \\
$\phi_{D, 2008}$ & -1.216 & 3.284 & 1.206 & -1.972 \\
& $(2.643)$ & $(2.628)$ & $(1.328)$ & $(7.785)$ \\
$\phi_{D, 2009}$ & -1.871 & 1.649 & $2.883^{* *}$ & -6.002 \\
& $(2.860)$ & $(2.954)$ & $(1.409)$ & $(7.263)$ \\
$\phi_{D, 2010}$ & 1.208 & 1.834 & 1.768 & -4.766 \\
& $(3.599)$ & $(3.932)$ & $(2.132)$ & $(8.135)$ \\
$\phi_{D, 2011}$ & 1.251 & 0.288 & 1.104 & $-13.84^{*}$ \\
& $(4.756)$ & $(3.723)$ & $(2.647)$ & $(7.535)$ \\
$\phi_{D, 2012}$ & -0.639 & 1.072 & 0.840 & -9.122 \\
& $(3.954)$ & $(3.185)$ & $(2.874)$ & $(5.897)$ \\
City FE & & & & \\
Year FE & Yes & Yes & Yes & Yes \\
Covariates & Yes & Yes & Yes & Yes \\
Observations & 2,927 & 2,927 & 2,927 & 2,927 \\
R-squared & 0.292 & 0.142 & 0.429 & 0.254 \\
\hline \hline
\end{tabular}

Significance level: *** significant at the $1 \%$ level; ${ }^{* *}$ significant at the $5 \%$ level; * significant at the $10 \%$ level.

Robust standard errors are clustered at the court level. 
Table A13: Estimation of the difference between cities not affected by the reform and cities that experienced a rise in the distance to the labor court (Conditional differences-in-differences, regressionadjusted, excluding non-treatable cities, Multilevel mixed effects).

\begin{tabular}{lcccc}
\hline \hline & Job Destruction & Job Creation & Unemployment & New Firms \\
\hline$\phi_{I, 2006}$ & 0.482 & 0.460 & -0.448 & 0.479 \\
$\phi_{I, 2008}$ & $(0.888)$ & $(1.393)$ & $(0.602)$ & $(2.684)$ \\
& -0.0243 & $-2.233^{* *}$ & $-1.125^{* *}$ & 4.586 \\
$\phi_{I, 2009}$ & $(0.799)$ & $(1.114)$ & $(0.457)$ & $(2.877)$ \\
& -0.0778 & $-5.086^{* * *}$ & -0.684 & -0.637 \\
$\phi_{I, 2010}$ & $(1.269)$ & $(1.310)$ & $(0.647)$ & $(2.049)$ \\
& $-2.120^{*}$ & $-5.739^{* * *}$ & -0.747 & -0.767 \\
$\phi_{I, 2011}$ & $(1.278)$ & $(1.725)$ & $(1.098)$ & $(1.905)$ \\
& $-2.600^{* *}$ & $-5.198^{* * *}$ & 0.624 & -1.975 \\
$\phi_{I, 2012}$ & $(1.182)$ & $(1.778)$ & $(1.452)$ & $(1.787)$ \\
& $-3.927^{* * *}$ & $-6.528^{* * *}$ & -0.0754 & $-3.358^{* *}$ \\
& $(1.148)$ & $(1.756)$ & $(1.537)$ & $(1.623)$ \\
City RE & & & & \\
Year FE & Yes & Yes & Yes & Yes \\
Court $\times$ Year RE & Yes & Yes & Yes & Yes \\
Covariates & Yes & Yes & Yes & Yes \\
Observations & 48,752 & Yes & Yes & Yes \\
\hline \hline
\end{tabular}

Significance level: ${ }^{* * *}$ significant at the $1 \%$ level; ${ }^{*}$ significant at the $5 \%$ level; ${ }^{*}$ significant at the $10 \%$ level. 
Table A14: Estimation of the difference between cities not affected by the reform and cities that experienced a fall in the distance to the labor court (Conditional differences-in-differences, regressionadjusted, excluding non-treatable cities, Multilevel mixed effects).

\begin{tabular}{lcccc}
\hline \hline & Job Destruction & Job Creation & Unemployment & New Firms \\
\hline$\phi_{D, 2006}$ & 0.400 & 0.332 & -1.540 & -2.149 \\
& $(1.407)$ & $(2.670)$ & $(1.677)$ & $(6.788)$ \\
$\phi_{D, 2008}$ & -0.695 & 3.195 & -0.370 & 6.541 \\
& $(2.217)$ & $(2.453)$ & $(1.083)$ & $(4.771)$ \\
$\phi_{D, 2009}$ & -1.422 & 0.717 & -0.583 & 2.556 \\
& $(2.405)$ & $(2.228)$ & $(1.229)$ & $(3.641)$ \\
$\phi_{D, 2010}$ & 2.087 & 1.099 & -1.639 & 5.029 \\
& $(2.560)$ & $(3.843)$ & $(1.563)$ & $(5.236)$ \\
$\phi_{D, 2011}$ & 1.635 & 0.749 & -0.834 & -6.513 \\
& $(3.289)$ & $(2.857)$ & $(3.062)$ & $(4.504)$ \\
$\phi_{D, 2012}$ & 0.111 & 2.078 & -1.116 & 1.995 \\
& $(2.431)$ & $(2.711)$ & $(3.026)$ & $(3.394)$ \\
City RE & & & & \\
Year FE & Yes & Yes & Yes & Yes \\
Court $\times$ Year RE & Yes & Yes & Yes & Yes \\
Covariates & Yes & Yes & Yes & Yes \\
Observations & Yes & Yes & Yes & Yes \\
\hline \hline
\end{tabular}

Significance level: ${ }^{* * *}$ significant at the $1 \%$ level; ${ }^{* *}$ significant at the $5 \%$ level; ${ }^{*}$ significant at the $10 \%$ level. 
Table A15: Linear estimation of the effect of a change of distance. (No matching-correction, including non-treatable cities.)

\begin{tabular}{lcccc}
\hline \hline & Job Destruction & Job Creation & Unemployment & New Firms \\
\hline$\phi_{2006}$ & -0.0155 & 0.0408 & 0.0177 & $-0.155^{* *}$ \\
& $(0.0365)$ & $(0.0378)$ & $(0.0194)$ & $(0.0702)$ \\
$\phi_{2008}$ & -0.0249 & $-0.0629^{*}$ & -0.00174 & -0.0419 \\
& $(0.0201)$ & $(0.0326)$ & $(0.0127)$ & $(0.0839)$ \\
$\phi_{2009}$ & -0.000262 & $-0.142^{* * *}$ & -0.00908 & $-0.120^{*}$ \\
& $(0.0428)$ & $(0.0421)$ & $(0.0232)$ & $(0.0660)$ \\
$\phi_{2010}$ & $-0.0904^{* * *}$ & $-0.133^{* *}$ & -0.0116 & $-0.134^{*}$ \\
& $(0.0290)$ & $(0.0528)$ & $(0.0302)$ & $(0.0751)$ \\
$\phi_{2011}$ & $-0.0933^{* * *}$ & $-0.0967^{*}$ & 0.0323 & $-0.108^{*}$ \\
& $(0.0332)$ & $(0.0565)$ & $(0.0492)$ & $(0.0604)$ \\
$\phi_{2012}$ & $-0.0942^{* * *}$ & $-0.119^{* *}$ & 0.0510 & $-0.212^{* * *}$ \\
& $(0.0330)$ & $(0.0515)$ & $(0.0452)$ & $(0.0459)$ \\
City FE & Yes & Yes & Yes & Yes \\
Year FE & Yes & Yes & Yes & Yes \\
Covariates & Yes & Yes & Yes & Yes \\
Observations & 57,119 & 57,116 & 57,115 & 56,142 \\
R-squared & 0.243 & 0.156 & 0.340 & 0.279 \\
\hline \hline
\end{tabular}

Significance level: $* * *$ significant at the $1 \%$ level; ${ }^{* *}$ significant at the $5 \%$ level; * significant at the $10 \%$ level.

Robust standard errors are clustered at the court level. 
Table A16: Linear estimation of the effect of a change of distance. (With matching-correction, including non-treatable cities.)

\begin{tabular}{lcccc}
\hline \hline & Job Destruction & Job Creation & Unemployment & New Firms \\
\hline$\phi_{2006}$ & -0.00746 & 0.00247 & 0.0152 & -0.0278 \\
& $(0.0324)$ & $(0.0327)$ & $(0.0184)$ & $(0.0658)$ \\
$\phi_{2008}$ & -0.00998 & $-0.109^{* * *}$ & -0.0118 & -0.00818 \\
& $(0.0202)$ & $(0.0269)$ & $(0.00969)$ & $(0.0840)$ \\
$\phi_{2009}$ & 0.00737 & $-0.176^{* * *}$ & -0.0206 & -0.0907 \\
& $(0.0435)$ & $(0.0358)$ & $(0.0234)$ & $(0.0647)$ \\
$\phi_{2010}$ & $-0.0858^{* * *}$ & $-0.160^{* * *}$ & -0.0197 & -0.106 \\
& $(0.0252)$ & $(0.0501)$ & $(0.0270)$ & $(0.0766)$ \\
$\phi_{2011}$ & $-0.0868^{* * *}$ & $-0.140^{* * *}$ & 0.0202 & -0.0620 \\
& $(0.0318)$ & $(0.0493)$ & $(0.0496)$ & $(0.0563)$ \\
$\phi_{2012}$ & $-0.0772^{* *}$ & $-0.144^{* * *}$ & 0.0448 & $-0.182^{* * *}$ \\
& $(0.0314)$ & $(0.0478)$ & $(0.0466)$ & $(0.0421)$ \\
City FE & Yes & Yes & Yes & Yes \\
Year FE & Yes & Yes & Yes & Yes \\
Covariates & Yes & Yes & Yes & Yes \\
Observations & 56,119 & 56,118 & 56,122 & 56,121 \\
R-squared & 0.229 & 0.188 & 0.332 & 0.290 \\
\hline \hline
\end{tabular}

Significance level: $* * *$ significant at the $1 \%$ level; ${ }^{* *}$ significant at the $5 \%$ level; * significant at the $10 \%$ level.

Robust standard errors are clustered at the court level. 